\title{
Lamina-Specific Expression of Adhesion Molecules in Developing Chick Optic Tectum
}

\author{
Masahito Yamagata, ${ }^{a}$ Jean-Paul Herman, ${ }^{\mathrm{b}}$ and Joshua R. Sanes \\ Department of Anatomy and Neurobiology, Washington University School of Medicine, St. Louis, Missouri 63110
}

The optic tectum is the major synaptic target of retinal axons in birds. In the chick, retinal ganglion cell axons enter the optic tectum through a superficial lamina (the stratum opticum), extend branches into deeper laminae, and arborize in specific "retinorecipient" laminae, where they form synapses. Studies using an organotypic culture system have provided evidence that the tectum bears a series of distinct, lamina-specific, cell surface-associated cues that direct these axonal behaviors (Yamagata and Sanes, 1995). Here, we have used a panel of antibodies to $\mathbf{3 0}$ membrane and matrix components to ask whether known adhesive molecules are distributed in lamina-specific patterns. Among many spatiotemporal pattern of expression documented, three were particularly noteworthy: (1) The cell adhesion molecules NgCAM/L1 and TAG-1/axonin-1 were concentrated in the stratum opticum. (2) SC1/JC7/DMGRASP/BEN, N-cadherin, neuropilin, polysialylated N-CAM, and glycoconjugates recognized by the lectin $V \mathrm{VA}-\mathrm{B}_{4}$ were concentrated in retinorecipient laminae. (3) Neurofascin, tenascin-C/cytotactin, and a matrix molecule defined by the "Sigma" antibody were present at highest levels in areas that border the retinorecipient laminae. Some members of each group (NgCAM/L1, TAG-1/axonin, SC1/JC7, polysialic acid, VVA-B ${ }_{4}$-receptors, and neurofascin) appeared on schedule and in lamina-restricted patterns in tecta from embryos that had been enucleated before retinal axons left the eye. Thus, molecules in these three categories could provide signals to retinal axons that promote extension through the stratum opticum, induce arborization or synaptogenesis in retinorecipient laminae, and prevent sprouting into adjoining laminae. Interestingly, $\mathrm{N}$-cadherin accumulated in retinorecipient laminae only following the onset of synapse formation, and failed to accumulate in enucleated tecta. Immunoelectron microscopy of normal tecta demonstrated the presence of $\mathrm{N}$-cadherin in the synaptic

\footnotetext{
Received Nov. 11, 1994; accepted Dec. 2, 1994.

We are grateful to many colleagues named in Materials and Methods for their generous gifts of antibodies, and to Dr. H. Fujisawa, S. Takagi, and colleagues (Nagoya University, Nagoya, Japan) for sharing unpublished data on neuropilin. We are also indebted to the Developmental Studies Hybridoma Bank at the University of Iowa, an invaluable center for the distribution of monoclonal antibodies. This work was supported by a grant from the NIH.

Correspondence should be addressed to Joshua R. Sanes, Department of Anatomy and Neurobiology, Washington University School of Medicine, 660 South Euclid Avenue, St. Louis, MO 63110.

aPresent address: Department of Molecular Neurobiology, National Institute for Basic Biology, Myodaiji, Okazaki, 444, Japan.

bPresent address: Faculté de Médecine Nord, Universitý Aix-Marseille, Marseille, cedex 20, France.

Copyright (c) 1995 Society for Neuroscience $0270-6474 / 95 / 154556-16 \$ 05.00 / 0$
}

cleft, suggesting a role for this molecule in synaptic maintenance.

[Key words: axon guidance, cell adhesion molecules, extracellular matrix, laminar formation, optic tectum, retinotectal projection]

In many parts of the vertebrate brain, somata of distinct neuronal types populate distinct laminae. The dendrites of such neurons often span several laminae, but specific classes of inputs to them are frequently confined to just one lamina. Thus, synapses as well as neurons are arranged in laminar patterns. Several factors can be envisioned that might explain how these patterns form. These include the subdivision of postsynaptic cell surfaces into domains that vary in their susceptibility to innervation; extraneuronal cues associated with glial cells and/or extracellular matrix; tropic factors that attract axons to appropriate laminae; and activity-dependent competitive interactions that refine initially diffuse projections (Bayer and Altman, 1987; Katz and Callaway, 1992; Bolz et al., 1993). At present, however, little is known about how any of these mechanisms contribute to the development of lamina-specific patterns of synaptic connectivity.

We have chosen to use the chicken optic tectum to investigate mechanisms of laminar selectivity. The tectum contains 15 distinct laminae, each of which bears a unique complement of neuronal types (Ramón y Cajal, 1911; LaVail and Cowan, 1971; Senut and Alvarado-Mallart, 1986). Ncurons from different laminae project to distinct extratectal targets, and extratectal inputs terminate in discrete laminae (Hunt and Brecha, 1984). Best studied among these is the retinal input (Mey and Thanos, 1992). Retinal axons enter the tectum through a superficial layer, the stratum opticum (SO), then branch and terminate in distinct retinorecipient laminae. All retinal arbors are confined to just $3-$ 4 of the 15 laminae, and each individual axon terminates in a single lamina (Angaut and Reperant, 1976; Acheson et al., 1980).

To begin to learn how retinal axons recognize retinorecipient laminae, we recently devised an organotypic culture system in which a transverse tectal section was overlaid with a retinal strip large enough to have unimpeded access to all tectal laminae. Outgrowth, branching, and arborization patterns of retinal axons were lamina selective on tectal slices, suggesting that a series of localized cucs guides axonal behaviors. Specifically, we hypothesized the existence of separate cues that: (1) promote outgrowth along the SO; (2) guide branching into deeper laminae; (3) induce arborization and synapse formation in the retinorecipient laminae; and (4) inhibit extension into adjoining (retinononrecipient) laminae. In addition, because retinal axons displayed lamina-selective behavior on tectal slices that had been chemi- 
cally fixed, we hypothesized that some of the cues are components of the cell surface (Yamagata and Sanes, 1995).

Testing these hypotheses will require identification of tectal molecules that guide retinal axons. As a first step toward this goal, we have documented the distribution of some membrane and matrix molecules that mediate adhesive interactions anong neural cells (Hynes and Lander, 1992; Goodman and Shatz, 1993; Sanes, 1993; Venstrom and Reichardt, 1993). Many of these have been demonstrated to be present in the chick optic tectum (Lemmon and McLoon, 1985; de la Rosa et al., 1990; Kroger and Schwarz, 1990; Lagonowich et al., 1992; Zhang et al., 1992; Halfter et al., 1993; Krushel et al., 1993; Perez and Halfter, 1993; Redies et al., 1993) but, with few exceptions, their laminar distribution has not been studied during the period when retinal axons arborizc and form synapses. We believed that this study would serve several purposes. First, few lamina-specific molecular markers are available for developmental studies in any system. Second, regardless of their functions, any such molecules could be used to study mechanisms of lamina formation. Finally, and most important, we hoped that this initial study would provide candidate molecules whose specific roles we could then test by immunological blockade (e.g., Bronner-Frascr and Lallier, 1988) or gene transfer (e.g., Galileo et al., 1992; Yamagata et al., 1994). Several intriguing candidates have emerged from this screen.

\section{Materials and Methods}

Animals. Fertilized White Leghorn chicken eggs were obtained from SPAFAS (Roanoke, IL), and incubated at $37.5^{\circ} \mathrm{C}$. Embryos that were developing normally, according to the Hamburger and Hamilton (1951) stage series, were used. For enucleation, both optic vesicles were removed at embryonic day (E) 3, as described previously (Yamagata and Sanes, 1995).

Antibodies. The antibodics used in this study are listed in Table 1. Most were generously provided by our colleagues: 224- IA6 and JG22E by Dr. D. I. Gottlieb (Washington University School of Medicine); $4 \mathrm{~d}$ by Dr. U. Rutishauser (Case Western Reserve School of Medicine); F6 by Drs. S. Chang and J. Raper (University of Pennsylvania School of Medicine); anti-TAG-1 by Drs. J. Dodd and T. M. Jessell (Columbia University College of Physicians and Surgeons); NCD2 by Dr. M. Takeichi (Kyoto University); B7 by Dr. E. Godfrey (Medical College of Wisconsin): Bravo, Kappa, and Sigma by Drs. W. Dreyer and J. Vielmetter (California Institute of Technology); anti-thrombospondin by Dr. W. Frazier (Washington University); and L2 and L3 by Dr. M. Schachner (Swiss Federal Institute of Technology). M1, 31, 33, R3/D6, 3A10, $\mathrm{BEN}$, JONES, D71E2, H1B4, P2C62C4, 5A5, 8A2, and 8D9 were obtained from the Developmental Studies Hybridoma Bank (Department of Biology, University of Iowa, Iowa City, IA). H23, JC7, C4, MY 174, and anti-aggrecan were generated in our laboratories. CS56 and biotinylated VVA-B, were purchased from Sigma (St. Louis, MO). Fluorescein- and horseradish peroxidase-conjugated second antibodies were purchased from Boehringer-Mannheim (Indianapolis, IN).

Immunofiuorescence staining. Tecta were immersion fixed for $5 \mathrm{hr}$ at $4^{\circ} \mathrm{C}$ with $1 \%$ paraformaldehyde in Hanks' solution supplemented with $20 \mathrm{~mm}$ HEPES, $1 \mathrm{mM} \mathrm{CaCl}_{2}$, and $1 \mathrm{~mm} \mathrm{MgCl}_{2}$. Then, the tecta were immersed for $2 \mathrm{hr}$ in $5 \%$ sucrose and overnight in $15 \%$ sucrose, both in Hanks' solution with HEPES, $\mathrm{CaCl}_{2}$, and $\mathrm{MgCl}_{2}$. Tecta were embedded in Tissue-Tek OCT compound (Miles Inc., Elkhart, IN), frozen on dry ice, and sectioned at $10 \mu \mathrm{m}$ in a cryostat. Sections were collected on subbed slides. For all antibodies except those that recognize glycolipids ( $\mathrm{L} 2, \mathrm{~L} 3,8 \mathrm{~A} 2$ ), the sections were then refixed in absolute methanol at $20^{\circ} \mathrm{C}$ for $30 \mathrm{~min}$. Sections were blocked for $30 \mathrm{~min}$ with $1 \% \mathrm{BSA}$ (for L2, L3, 5A5, 8A2, and VVA-B ${ }_{4}$ ) or $5 \%$ skim milk (for other antibodies) in PBS. Antibodies or lectins were diluted in the appropriate blocking solution, and applied to the sections for $2-3 \mathrm{hr}$ at $20^{\circ} \mathrm{C}$. After washing, slides were incubated for an additional $1 \mathrm{hr}$ with the nuclear counterstain DAPI $(0.5 \mu \mathrm{g} / \mathrm{ml}$, Molecular Probes, Eugene, OR) mixed with fluorescein-conjugated second antibodies or streptavidin. Finally, sections were mounted with $90 \%$ glycerol supplemented with p-pheneylendiamine, observed with a Nikon epifluorescence microscope, and photographed. Except where indicated, all observations were made on sections of anterior tectum.

Immunoelectron microscopv. Embryos were perfused with oxygenated Hanks' solution containing $10 \mu \mathrm{g} / \mathrm{ml}$ heparin, and then with $4 \%$ paraformaldehyde and $0.25 \%$ glutaraldehyde in $0.1 \mathrm{M}$ phosphate buffer, $\mathrm{pH}$ 7.2. Tecta were then removed from the embryos, and postfixed in the same solution at $4^{\circ} \mathrm{C}$ for $1 \mathrm{hr}$ and in $3.5 \%$ paraformaldehyde in Hanks' solution supplemented with $10 \mathrm{~mm}$ HEPES, pH 7.2, at $4^{\circ} \mathrm{C}$ for $12 \mathrm{hr}$. Fixed tecta were mounted in $1 \%$ agarose, and sectioned at 100 $\mu \mathrm{m}$ with a Vibratome. Sections were treated with $1 \% \mathrm{NaBH}_{4}$ in PBS at room temperature for $30 \mathrm{~min}$, washed extensively with $150 \mathrm{mM} \mathrm{NaCl}$, $50 \mathrm{~mm}$ Tris $\mathrm{HCl}, \mathrm{pH} 7.4$ (TBS), and inmersed in $2 \%$ BSA in TBS. For immunochemical staining, the sections were blocked in $5 \%$ normal goat serum in TBS, then incubated with the primary antibody in BSA/TBS overnight at $4^{\circ} \mathrm{C}$. The sections were then washed with TBS and incubated overnight at $4^{\circ} \mathrm{C}$ in horseradish peroxidase-conjugated secondary antibodies. For staining with $\mathrm{VVA} \mathrm{B}_{4}$, the protocol was similar except that blocking with normal goat serum was omitted and detection was with peroxidase-conjugated avidin. After extensive washing, the peroxidase was detected with $0.5 \mathrm{mg} / \mathrm{ml}$ diaminobenzidine in $50 \mathrm{~mm}$ Tris $\mathrm{HCl}, \mathrm{pH} \mathrm{7.4,} \mathrm{to} \mathrm{which} \mathrm{were} \mathrm{added} 10$ units of glucose oxidase (Sigma G-6891), $40 \mu \mathrm{g} / \mathrm{ml}$ ammonium chloride, and $200 \mu \mathrm{g} / \mathrm{ml}$ glucose. The sections were washed in $100 \mathrm{~mm}$ sodium cacodylate, $\mathrm{pH} 7.4$, dehydrated with propylene oxide, and embedded in plastic. Ultrathin sections were collected on Formvar-coated grids, and observed without further staining with a JEM-100 electron microscope (JOEL Ltd., Tokyo).

Nomenclature for tectal laminae. In mature (posthatching) tecta, we use laminar nomenclature proposed by Huber and Crosby (1933), and modified by LaVail and Cowan (1971). This system recognizes six main laminae; from pia to ventricle, they are: stratum opticum (SO), stratum griseum et fibrosum superficiale (SGFS), stratum griseum centrale or (SGC), stratum album centrale (SAC), stratum griseum periventriculare (SGP), and stratum fibrosum periventriculare (SFP). The SGFS is subdivided into 10 laminae, $a-j ; b, d$, and $f$ are the retinoreceptive laminae on which we focus in this paper (Fig. $1 a, b$ ). In developing tecta, LaVail and Cowan (1971) designated laminae by Roman numerals. This was necessary because lamination patterns change rapidly at early stages. By E10, however, all six of the main laminae and most subdivisions of SGFS are readily identifiable, so we have chosen to retain the adult names. However, subdivisions of the embryonic SGFS are designated by upper case letters, to distinguish them from the definitive laminae, which are designated by lower case letters. The correspondence between our nomenclature and that of LaVail and Cowan (1971), which renames subdivisions of the SGFS at $2 \mathrm{~d}$ intervals, is indicated in Figure $1 a$.

\section{Results}

Figure $1 b$ summarizes results of previous studies, which have described the arborization of retinal axons in the retinorecipient laminae of the optic tectum (Acheson et al., 1980; McLoon, 1985; Thanos and Bonhoeffer, 1987; Nakamura and O'Leary, 1988; Yamagata and Sanes, 1995). Axons enter the tectum through the SO at $E 8$, and (in anterior tectum) remain confined to this superficial layer until E10. By E12, many axons have left the SO, by perpendicular branching or oblique extension, and formed simple but broad arbors just beneath it. Then, after what appears to be a brief "waiting period" at the base of the SO, the retinal axons extend to the definitive retinorecipient laminae at E13-14, and begin to form rudimentary arbors. At this stage, most of the arbors are confined to a single one of the retinorecipient laminae (SGFS B or D), but some spread over both of these laminae. Between E14 and E16, further branching occurs, but some branches are apparently lost as well, because individual arbors become confined to a single retinorecipient lamina (SGFS B, D, or F; F forms between E14 and E16). Arbors continue to increase in complexity until at least $\mathrm{P} 2$, the latest stage we have examined.

To characterize the terrain that retinal axons encounter as they form synapses in the tectum, we stained cryostat sections of developing tectum with a panel of antibodies to cell surface 


\begin{tabular}{|c|c|c|}
\hline Antigen & Antibody & Reference \\
\hline \multicolumn{3}{|l|}{ Immunoglobulin superfamily } \\
\hline \multirow[t]{2}{*}{ N-CAM } & 224-1A6 & Lemmon et al., 1982 \\
\hline & $4 \mathrm{~d}$ & Watanabe et al., 1986 \\
\hline \multirow[t]{2}{*}{$\mathrm{NgCAM} / \mathrm{L} 1$} & $8 \mathrm{D} 9$ & Lagenaur and Lemmon, 1987 \\
\hline & $\mathrm{H} 23$ & Herman and Sanes, unpublished observations \\
\hline Bravo/NrCAM & Bravo & de la Rosa et al., 1990 \\
\hline F11/contactin(F3) & Kappa & W. Dreyer, unpublished observations \\
\hline TAG-1/Axonin-1 & $23.4-5$ & Dodd, J., unpublished observations \\
\hline \multirow[t]{2}{*}{ SC. $1 / \mathrm{JC} 7$} & $\mathrm{JC7}$ & El-Deeb et al.. 1992 \\
\hline & BEN & Pourquie et al., 1992a \\
\hline Neurofascin & F6 & Rathjen et al., 1987 \\
\hline \multicolumn{3}{|l|}{ Cadherins } \\
\hline N-cadherin & $\mathrm{NCD} 2$ & Hatta et al., 1987 \\
\hline L-CAM & 7D6 & Gallin et al., 1982 \\
\hline \multicolumn{3}{|l|}{ Integrins } \\
\hline$\beta 1$ & JG22E & Greve and Gottlieb, 1982 \\
\hline$\alpha 5$ & D7IE2 & Lakonishok et al., 1992 \\
\hline$\alpha 6$ & $\mathrm{P} 2 \mathrm{C} 62 \mathrm{C} 4$ & Bronner-Fraser et al., 1992 \\
\hline$\alpha 7$ & H1B4 & Bao et al., 1993 \\
\hline \multicolumn{3}{|l|}{ Extracellular matrix } \\
\hline Tenascin-C/cytotactin & M1 & Chiquet and Fambrough, 1984 \\
\hline Heparan sulfate proteoglycan & 33 & Bayne et al., 1984 \\
\hline Laminin & 31 & Bayne et al., 1984 \\
\hline S-laminin & $\mathrm{C} 4$ & Hunter et al., 1989 \\
\hline Agrin & B7 & Godfrey et al., 1988 \\
\hline Fibronectin & B3/D6 & Gardner and Fambrough, 1983 \\
\hline Versican & MY174 & Yamagata et al., 1993 \\
\hline Aggrecan & Polyclonal & Yamagata et al., 1993 \\
\hline Sigma & Sigma & W. Dreyer, unpublished observations \\
\hline Thrombospondin & Polyclonal & W. Frazier, unpublished observations \\
\hline \multicolumn{3}{|l|}{ Carbohydrates } \\
\hline Chondroitin sulfate & $\operatorname{CS} 56$ & Avnur and Geiger, 1984 \\
\hline Keratan sulfate & 5D4 & Caterson et al., 1983 \\
\hline L2/HNK1 & L2 & Kruse et al., 1984 \\
\hline L3 & L3 & Kucherer et al., 1987 \\
\hline GalNAc-X & VVA-B 4 & Scott et al., 1988 \\
\hline Polysialic acid & 5 A. 5 & Dodd et al., 1988 \\
\hline Ganglioside 8A2 & $8 \mathrm{~A} 2$ & Drazba et al., 1990 \\
\hline
\end{tabular}

Identical results were obtained with $8 \mathrm{D} 9$ and $\mathrm{H} 23$ and with JC7 and BEN. 224-IA6, which recognizes all N-CAM forms, and $4 \mathrm{~d}$, which recognizes $\mathrm{N}-\mathrm{CAM} \sim 180$, stained tectum identically; however, only the former stained meninges, consistent with the known restriction of N-CAM-180 to neurons (Polleberg et al., 1985).

molecules. Three ages were selected for initial studies: E12, when retinal axons have extended through the $\mathrm{SO}$ and begun to branch into deeper layers; E14, as rudimentary arbors begin to form in the retinorecipient laminae; and E18, when laminaspecific arbors are relatively mature. Sections were counterstained with the nuclear dye DAPI to permit identification of laminar boundaries. As expected, this screen revealed a variety of distributions. For detailed study, we focused on antibodies that selectively stained the SO or subsets of laminae within SGFS. Two molecules were concentrated in the SO (NgCAM/ $\mathrm{L} 1$ and axonin-1/TAG-1); five in the retinorecipient portions of SGFS (polysialylated N-CAM, SC I/JC7/DM-GRASP/BEN, VVA-B ${ }_{4}$-binding glycoconjugates, neuropilin, and $\mathrm{N}$-cadherin); and three in areas that directly abutted retinorecipient laminae (neurofascin, tenascin-C, and Sigma).

\section{Molecules concentrated in the SO}

$\mathrm{NgCAM} / L I / G 4 / 8 D 9 / N I L E$ (referred to hereafter as NgCAM/ L1) is a transmembrane protein of the immunoglobulin superfamily that is expressed in subsets of axons throughout the central and peripheral nervous systems (Burgoon et al., 1991). In tectum, $\mathrm{NgCAM} / \mathrm{LI}$ is concentrated in the $\mathrm{SO}$ from as early as E8 until after hatching. $\mathrm{NgCAM} / \mathrm{Ll}$ is also abundant on the tectobulbar axons of the SAC from E8 to E12, but disappears at later times (Lemmon and McIoon, 1986; Kröger and Schwarz, 1990). It is virtually undetectable in the retinoreceptive laminae of SGFS and in the SGC, at all stages examined, but is present in SGFS H. Electron microscopic immunohistochemistry has shown that much of the $\mathrm{NgCAM} / \mathrm{L} 1$ in the SO is associated with retinal axons (Lemmon and McLoon, 1986). At E8, as the NgCAM/L1-positive retinal axons arrived in ros- 
a) LAMINAE

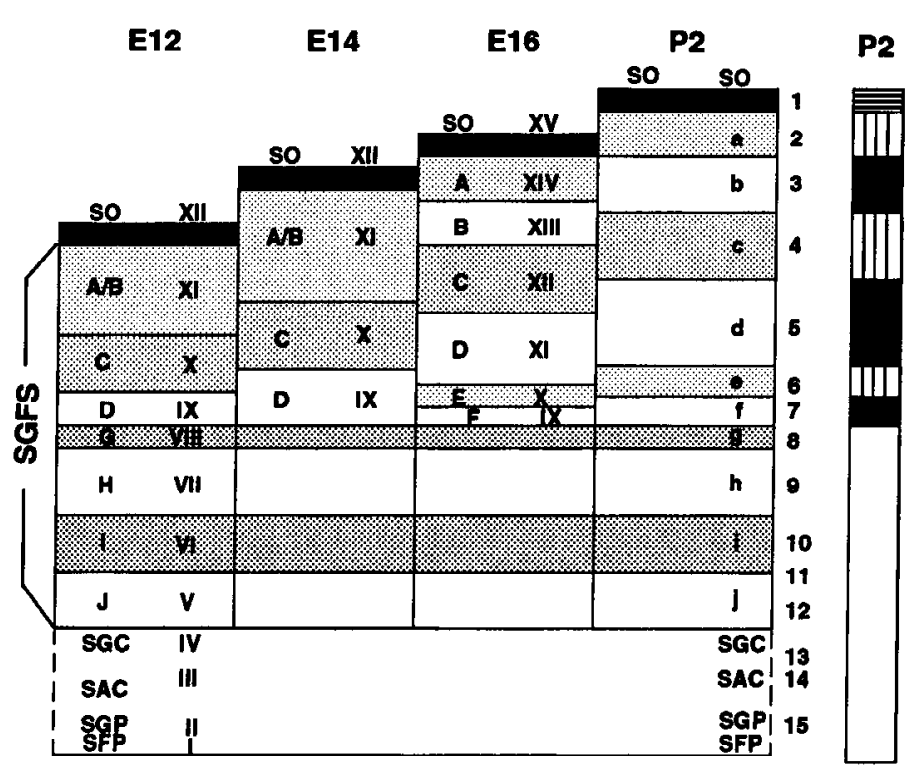

c) RETINAL ARBORS

E12

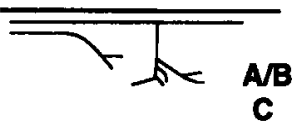

E16
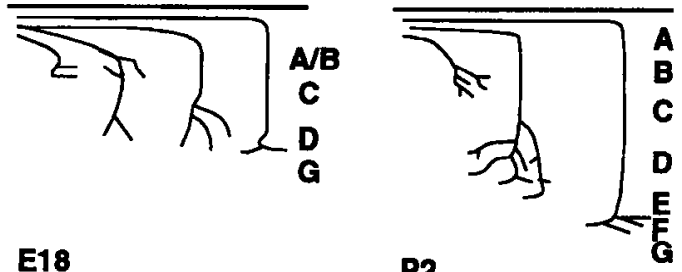

E18
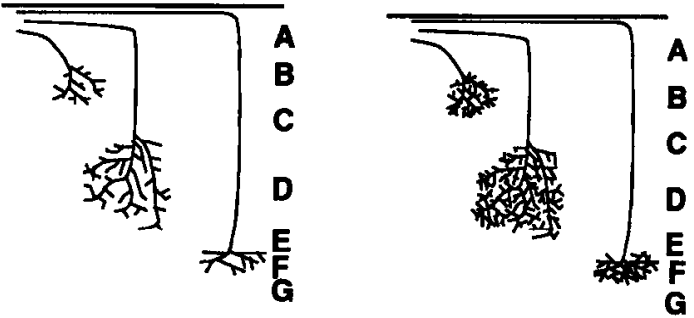

Figure 1. Summary of tectal development. $a$, Maturation of tectal laminae, indicating the nomenclature we use (on the left at each stage) and its correspondence to the system of LaVail and Cowan (1971; on the right). The numbering system of Ramon y Cajal (1911), which applies only to the mature tectum, is shown at the far right. Laminar patterns were determined with a nuclear counterstain, as shown in Figure 2. See Materials and Methods for full names of laminae. $b$, Laminae in which retinal axons extend (parallel lines) and terminate (black bars), based on bulk labeling and electron microscopy. $c$; Timing of the ingrowth, branching, and arborization of retinal axons in anterior tectum, based on observations with anterograde tracers.

tral tectum, they extended within the SO (Fig. 2a). Most axons ran deep to the external limiting membrane, within an NgCAM/ L1-negative environment of unknown composition (arrowheads in Fig. 2a). Even at later times the retinorecipient laminae of SGFS remained $\mathrm{NgCAM} / \mathrm{L} 1$ negative (Fig. $2 e, i$ ). The absence of $\mathrm{NgCAM} / \mathrm{L} 1$ from SGFS at times when retinal arbors are profuse suggests that it is excluded from retinal terminals.

Axonin-1/TAG-1. A mepber of the immunoglobulin superfamily, axonin-1/TAG-1 occurs in both membrane-anchored and secreted forms. TAG-1 was identified in rodents (Furley et al., 1991). Axonin-1 was identified as an adhesion molecule in chick, and shown by molecular cloning to be the avian ortholog of TAG-1 (Zuellig et al., 1992). Axonin-1/TAG-1, like NgCAM/ $\mathrm{LI}$, was associated with both the SO and the SAC at E8. However, the localization of these two members of the immunoglobulin superfamily differed in both laminae. In the SO, anti-axonin-1/TAG-1 labeled fibers that were perpendicular to the $\mathrm{NgCAM} / \mathrm{L}$ 1-positive retinal axons (Fig. $2 a, b$ ). In the $\mathrm{SAC}$, axonin-1/TAG-1-positive fibers were concentrated at the superficial and deep margins of the $\mathrm{NgCAM} / \mathrm{L} 1$-positive tectobulbar tract (Fig. 2c,d). The axonin-1/TAG-1-positive fibers in the SO persisted through E12, and became displaced toward the base of the $\mathrm{SO}$ as ingrowth of retinal axons caused this lamina to thicken (Fig. $2 g$ ). The SO was less intensely stained at E14 than at E12 (Fig. $2 k$ ), and was axonin-1/TAG-1 negative by E16, indicating that either the expression of axonin-1/TAG-1 or the axonal tract itself was transient.

Two observations suggested that the axonin-1/TAG-1-positive axons were extraretinal in origin. First, the axonin-1/TAG-1-positive fibers were oriented parallel to the tectobulbar tract of the SAC and perpendicular to the retinal axons (Fig. 2a,b). Two, the axonin-1/TAG-1-positive tract was detectable in the posterior portion of the prospective SO at $\mathrm{E} 8$, when $\mathrm{NgCAM} / \mathrm{L1}$-positive retinal axons had grown only as far as the central tectum (Fig. $2 c, d)$. This early appearance suggests that the axonin-1/TAG-1positive fibers could form a scaffold across which retinal axons grow. To confirm the extraretinal origin of these fibers, we turned to enucleated tecta.

Expression in enucleated tecta. Molecules concentrated in the SO might provide signals for ingrowing axons. Alternatively, they might be present on retinal axons. To distinguish these possibilities, we studied tecta from embryos that had been enucleated bilaterally at E3, which is several days before any retinal axons reach the tectum. When tecta develop in enucleated embryos, the SO is greatly attenuated, but still distinguishable. Consistent with its presence on retinal axons, $\mathrm{NgCAM} / \mathrm{Ll}$-like immunoreactivity has been shown to be absent from the superficial laminae of E8 tecta following enucleation at E2 (de la Rosa et al., 1990) or E3 (Lemmon and McLoon, 1986). In contrast, when we stained E12 or E14 tecta from embryos that had been bilaterally enucleated at E3, a thin but intense band of NgCAM/ L1-like immunoreactivity was present at the base of the remnant of the SO (Fig. $2 f, g, i, j$ ). This result indicates that some NgCAM/ L1-positive components of the SO are of nonretinal origin, and that these appear (or become $\mathrm{NgCAM} / \mathrm{L} 1$ positive) between $\mathrm{E} 8$ and E12. Likewise, axonin-1/TAG-1 immunoreactivity survived bilateral enucleation (Fig. $2 h$ ).

\section{Molecules concentrated in retinorecipient laminae}

Polysialic acid. A polysaccharide consisting of $\alpha 2-8$-linked chains of sialic acid residues decorates specific subsets of N-CAM molecules, especially in embryos (Rutishauser, 1992). 

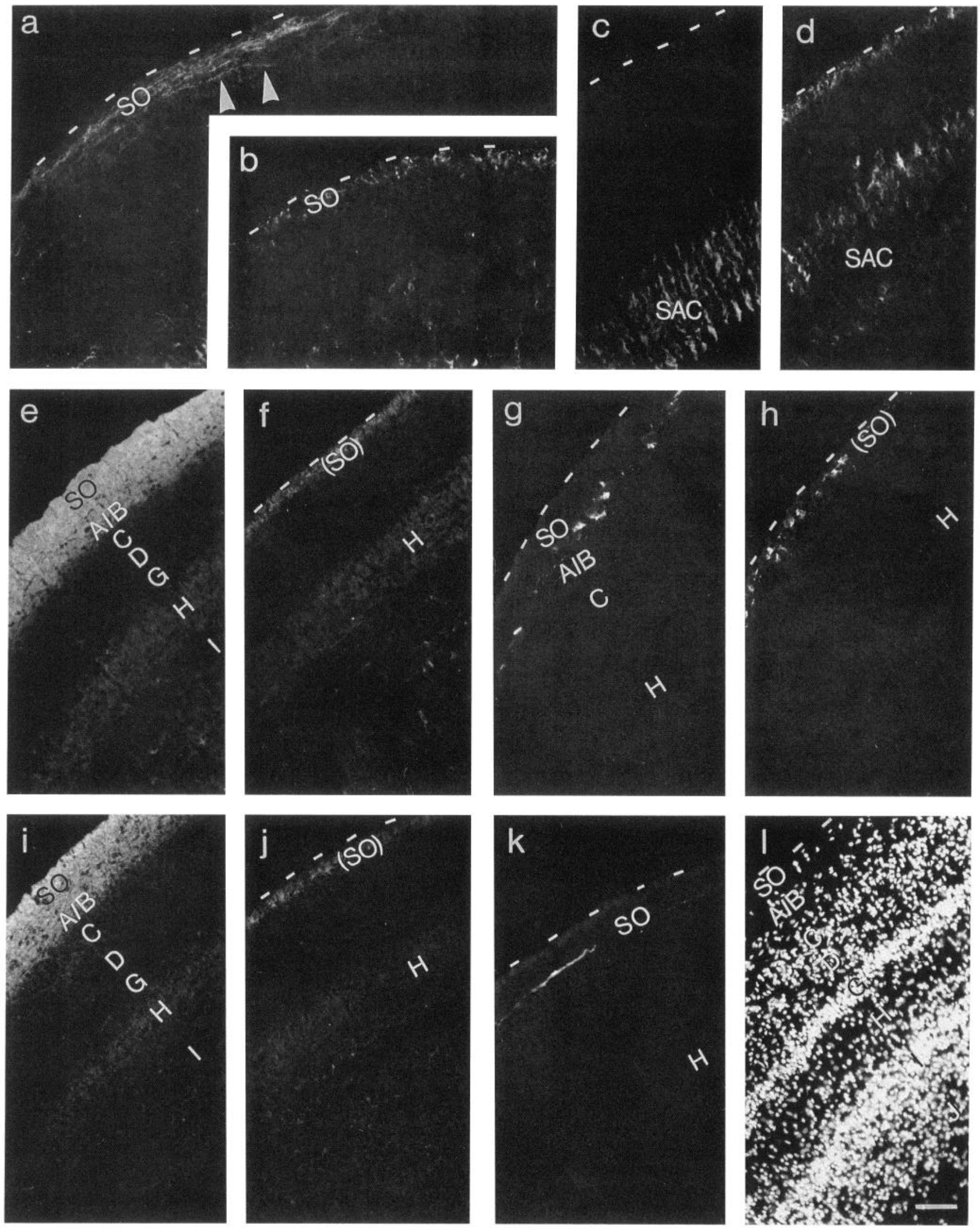

Figure 2. NgCAM/L1 and axonin-1/TAG-1 are concentrated in the stratum opticum. $a-d, \mathrm{E} 8 ; e-h, \mathrm{E} 12 ; i-l, \mathrm{E} 14 . a$ and $c$ are micrographs from the most anterior $(a)$ and middle $(c)$ parts of a parasaggital section, stained with anti- $\mathrm{NgCAM} / \mathrm{L} 1$. Retinal axons in the SO (arrowheads) and tectobulbar axons in the SAC are stained. $b$ and $d$ are from corresponding regions of an adjacent section, stained with anti-axonin-1/TAG-1. TAG1-positive fibers are present at the superficial margin of the SO, and at both margins of the tectobulbar tract. At E12, $\mathrm{NgCAM} / \mathrm{L} 1$ remains abundant throughout the SO $(e)$, and axonin-1/TAG-1 remains confined to a narrower portion of the SO, at its deeper aspect $(g) . f$ and $h$ are sections of 

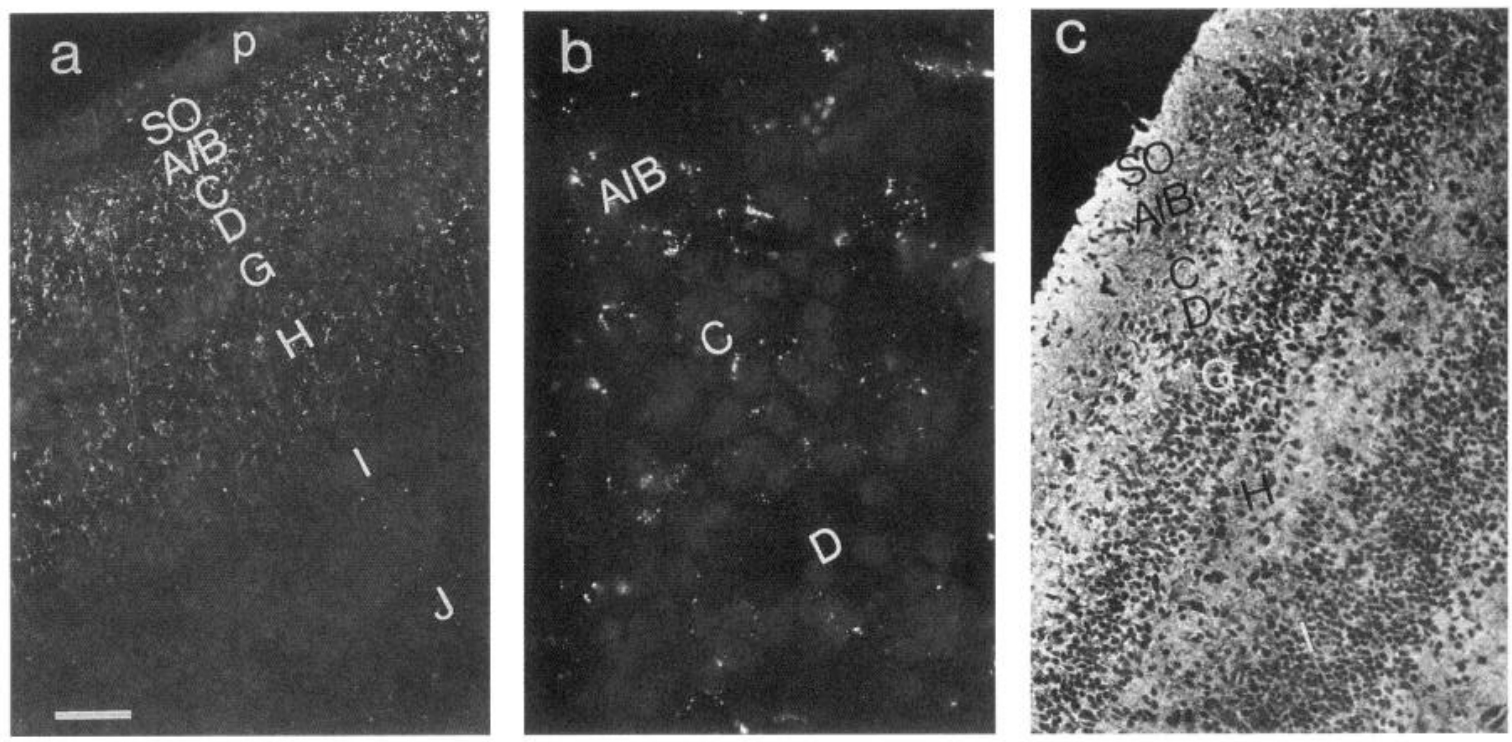

Figure 3. Polysialic acid is concentrated in retinorecipient laminae before retinal axons arrive. Sections of E12 tectum stained with a monoclonal antibody to polysialic acid are shown at low power to illustrate the laminar distribution of the antigen $(a)$, and at high power to show the punctate nature of the immunoreactive material $(b) . c$ is a similar section stained with anti-N-CAM, to show that the polysialylated $\mathrm{N}-\mathrm{CAM}$ is more restricted in its distribution than N-CAM in general. $P$, pial. Bar is $50 \mu \mathrm{m}$ for $a$ and $c$, and $10 \mu \mathrm{m}$ for $b$.

N-CAM appears to be the only protein to bear this unique carbohydrate (Cremer et al., 1994); so, antibodies to polysialic acid can be used to reveal the location of the polysialylated subpopulations of N-CAM molecules. Throughout the period we studied, $\mathrm{N}-\mathrm{CAM}$ was present at similar, readily detectable levels in all tectal laminae. Polysialylated N-CAM, in contrast, displayed a more restricted distribution. At E10-E12, polysialic acid was present at high levels in the prospective retinorecipient laminae (SGFS A-D) and in one deeper lamina (SGFS H), but was nearly absent from the laminae directly abutting the retinorecipient zone (SO and SGFS E-G, respectively; Fig. $3 a$; see also Zhang et al., 1992). The distribution of polysialic acid within SGFS AD was strikingly punctate (Fig. $3 b$ ), suggesting that even in these laminae it was associated with a subpopulation of the more homogeneously distributed N-CAM molecules (Fig. $3 c$ ). Levels of polysialic acid had decreased by E12, and the epitope was undetectable from E14 onwards.

$V V A-B_{4}$. Vicia villosa $\mathrm{B} 4$ isoagglutinin $\left(\mathrm{VVV}-\mathrm{B}_{4}\right)$ is a plant lectin with a nominal specificity for terminal $\mathrm{N}$-acetylgalactosaminyl (GalNAc) residues (Piller et al., 1990). This lectin and others with similar specificities selectively stain neuromuscular junctions in skeletal muscle (Sanes and Cheney, 1982; Scott et al., 1988), and perineural nets of extracellular matrix surrounding defined subsets of neurons in the mammalian brain (Celio, 1993). In the tectum, VVA-B ${ }_{4}$ selectively stained the superficial portion of the tectal plate at E10 (Fig. 4). By E12, the strongest staining was in SGFS D, with lighter reactivity extending from to SGFS C to SGFS G (Fig. 5a). Staining was qualitatively similar at E14, although SGFS D widened considerably during this interval (Fig. 5b). At E16, when SGFS F appeared, this lamina was also stained (not shown). The intensity of staining decreased by E18, although laminar selectivity was retained (Fig. $5 c$ ), and the most prominently VVA- ${ }_{4}$-stained structures in tecta of posthatched chicks were blood vessels (not shown).

To further study the relationship between changes in the pattern of VVA- $\mathrm{B}_{4}$ staining and the ingrowth of retinal axons, we double labeled parasaggital sections of E9-E11 tecta with VVA$\mathrm{B}_{4}$ and anti-NgCAM/L1. As noted above, $\mathrm{NgCAM} / \mathrm{L} 1$ marks retinal axons, which extend only partway along the tectal surface at these ages (Fig. 4a). In posterior tectum, VVA-B ${ }_{4}$ stained a broad band centered on the region destined to bear retinorecipient laminae. In areas surmounted by retinal axons, however, the VVA-B ${ }_{4}$-positive band was narrower and corresponded more precisely to SGFS D (Fig. 4b). This precise correspondence suggested that retinal axons induced the redistribution of VVA- $\mathrm{B}_{4}$ binding glycoconjugates. However, VVA- $\mathrm{B}_{4}$ selectively stained retinorecipient laminae of enucleated tecta at E12 and E14 (see below), indicating that the restriction of VVA- $\mathrm{B}_{4}$ staining to retinorecipient laminae is correlated with but not dependent on ingrowth of retinal axons.

All staining by VVA-B ${ }_{4}$ was inhibited by inclusion of $10 \mathrm{~mm}$ GalNAc in the incubation solution but was unaffected by $10 \mathrm{~mm}$ $\mathrm{N}$-acetylglucosamine or galactose, consistent with the nominal specificity of this lectin for GalNAc residues. Helix pomatia agglutinin (HPA) and soybean agglutinin (SBA), which are also GalNAc specific (Piller et al., 1990), stained tecta similarly to VVA- $B_{4}$, but less intensely. VVA- $B_{4}$ staining was unaffected by the prior extraction of sections with acetone, methanol, or chloroform: methanol mixtures, suggesting that the reactive material is associated with glycoproteins rather than glycolipids. Consis-

$\leftarrow$

E12 tecta from enucleated embryos, stained with anti-NgCAM/L1 $(f)$ and anti-axonin-1/TAG-1 $(h)$. Most of the axonin-1/TAG-1 but only a smal fraction of the $\mathrm{NgCAM} / \mathrm{L} 1$ survives enucleation. At E14, $\mathrm{NgCAM} / \mathrm{Ll}$ is still present at high levels in the SO $(i)$, but levels of axonin-1/TAG-1 have decreased $(k), j$ is from an E14 enucleated embryo, stained with anti-axonin-1/TAG-1. $l$ is an E14 section similar to those in $i-l$, stained with DAPI, to show that laminae are readily distinguishable with a nuclear counterstain. Pial surface is marked with dashes. (SO) marks superficial layer in enucleated tecta. Bar is $70 \mu \mathrm{m}$ for $a-d$, and $50 \mu \mathrm{m}$ for $e-l$. 


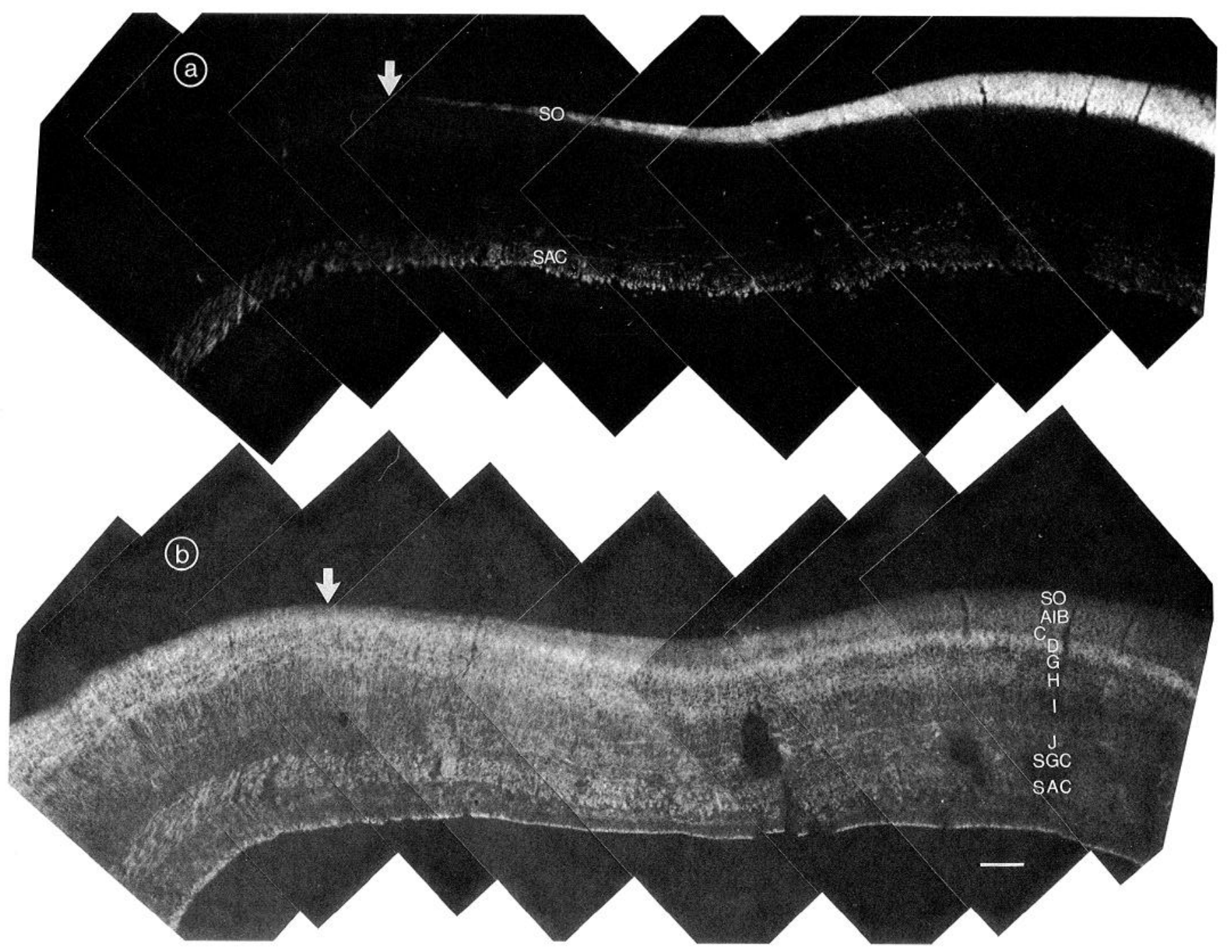

Figure 4. VVA- $\mathrm{B}_{4}$-binding glycoconjugates become concentrated in retinorecipient laminae as retinal axons invade. Montage of micrographs from a parasaggital section of E10 tectum, doubly labeled with anti-NgCAM/L1 $(a)$ and VVA- $\mathrm{B}_{4}(b)$. Anterior is at the right. Arrow marks posterior extent of retinal axons. Bar is $50 \mu \mathrm{m}$.

tent with this conclusion, the retinorecipient laminae were not detectably stained by antibodies to any of three GalNAc-terminated glycolipids, GM2, SSEA-3, or the Forssman antigen (not shown).

$S C 1 / J C 7 / D M-G R A S P / B E N$ (referred to hereafter as SC1/JC7) is a cell surface glycoprotein of the immunoglobulin superfamily, which was initially isolated because it was expressed by subsets of neurons in spinal cord and peripheral ganglia (BEN, Pourquíe et al., 1992a; SC1, Tanaka et al., 1991; JC7, El-Deeb et al., 1992; DM-GRASP, Burns et al., 1991). In the tectum, the distribution of SC1/JC7 varied dramatically with age. At E8, it was associated with the tectobulbar tract, and at E10 it appeared in the most superficial portion of the forming tectal plate (presumptive SGFS; not shown). At E12-E14, low levels of SC1/ JC7 were detectable throughout the tectum, but highest levels of immunoreactivity were sharply localized to a single retinorecipient lamina, SGFS D (Fig. 6a,b). On E16, staining decreased in SGFS D and became prominent in SGFS F (Fig. 6c). By E18, $\mathrm{SC} 1 / \mathrm{JC} 7$ levels had decreased in all retinorecipient laminae, and the antigen was again homogeneously distributed at a low level throughout the tectum (Fig. $6 d$ ).
Based on the similar staining patterns of $\mathrm{SCl} / \mathrm{JC} 7$ and VVA$\mathrm{B}_{4}$-reactive material, it is possible that $\mathrm{SC1} / \mathrm{JC} 7$ (and/or neuropilin; see below) might bear the VVA-B $\mathrm{B}_{4}$-reactive carbohydrate. However, the band of VVA-B $\mathrm{B}_{4}$-reactive material was broader than that stained by antibodies to either $\mathrm{SC} 1 / \mathrm{JC} 7$ or neuropilin, indicating that at least some VVA- $\mathrm{B}_{4}$-reactive carbohydrates are associated with other molecules.

$N$-cadherin. A member of the cadherin family of calciumdependent cell adhesion molecules, $\mathrm{N}$-cadherin appears to play numerous roles in early neural development as well as in later events such as lamina formation (Takeichi, 1990). N-cadherin was broadly distributed at low levels in tecta at E8-E12 (Fig. $7 a$ ), consistent with previous reports (Lagunowich et al., 1992; Redies et al., 1993). At E14, enhanced staining was observed in SGFS B and D (Fig. 7b). The staining of laminae B and D became more intense as development proceeded (Fig. 7c).

Expression in enucleated tecta. We stained sections from enucleated tecta with antibodies to components of retinorecipient laminae, to learn whether their expression reflected and/or was regulated by retinal axons. The concentration of polysialic acid in retinorecipient laminae and its disappearance after E12 were 

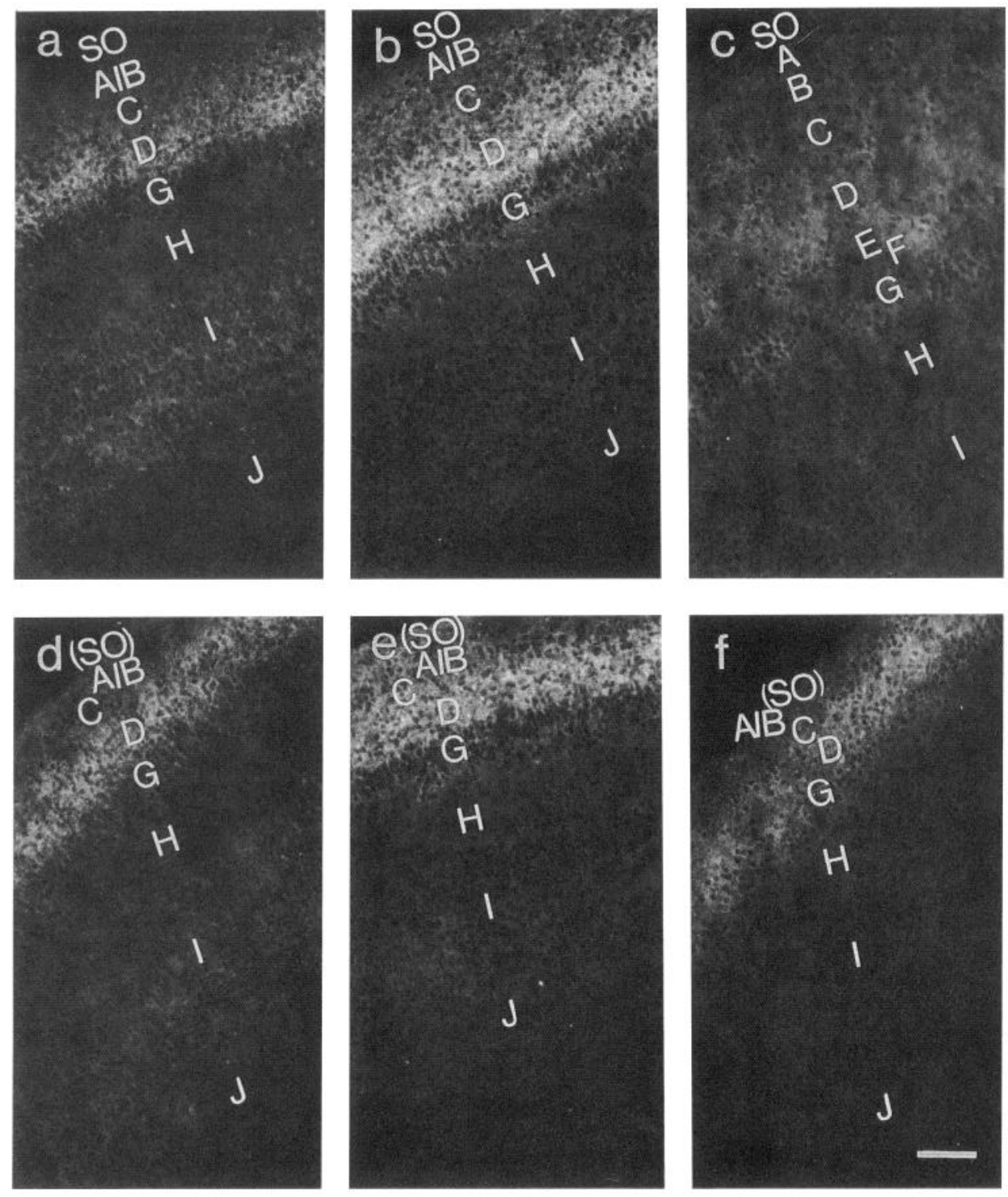

Figure 5. Glycoconjugates recognized by the lectin VVA-B ${ }_{4}$ are concentrated in retinorecipient laminae. Sections of normal $(a-c)$ or enucleated $(d-f)$ tectum were stained with VVA$\mathrm{B}_{4}$ lectin at $\mathrm{E} 12(a, d), \mathrm{E} 14(b, e)$, and E18 $(c, f)$. (SO) marks superficial layer in enucleated tecta. Bar is $50 \mu \mathrm{m}$.

unperturbed by enucleation at E3 (not shown), indicating that neither its distribution nor its levels were greatly affected by retinal input. Likewise, the concentration of $\mathrm{VVA}^{-\mathrm{B}_{4}}$-binding material and $\mathrm{SC} 1 / \mathrm{JC} 7$ in retinorecipient laminae at E12 and E14 was not markedly affected by enucleation (Figs. $5 d, e, 6 e, f$ ). In contrast, the decrease in VVA-B $\mathrm{B}_{4}$ and JC7 staining that occurred in control tecta between E14 and E18 was less pronounced in enucleated tecta (Figs. $5 f, 6 h$ ), raising the possibility that disappearance of these components is promoted by the formation or activation of retinotectal synapses. Moreover, enucleation prevented the accumulation of $\mathrm{N}$-cadherin in retinorecipient laminae between E12 and E18 (Fig. $7 d-f$ ), consistent with evidence that $\mathrm{N}$-cadherin is expressed by retinal ganglion cells (Matsanuga et al., 1988).

Ultrastructural localization of SCI/JC7, VVA-B-binding carbohydrates, and $N$-cadherin. We used immunoelectron microscopy to determine the subcellular localization of molecules concentrated in retinorecipient laminae. Vibratome sections of tecta were stained with anti-SC1/JC7 at E14, with anti-N-cadherin at E18, and with VVA-B ${ }_{4}$ at both ages. Sites of antibody or lectin binding were then revealed with a peroxidase method, and thin sections through the retinorecipient laminae were examined in the electron microscope. All three components were present on cellular membranes, but their localizations differed. VVA-B ${ }_{4}^{-}$ binding material (Fig. $8 a$ ) and $\mathrm{SC} 1 / \mathrm{JC} 7$ (Fig. $8 b$ ) were widely distributed in the neuropil, and appeared to be associated with both axonal and dendritic processes. In contrast, $\mathrm{N}$-cadherin was concentrated at synaptic contacts (Figs. $8 c-e$ ). The staining was associated with synaptic clefts, as expected for an antibody that recognizes an extracellular epitope (NCD2; Matsunaga et al., 1988). Stained synapses were asymmetric and contained spherical synaptic vesicles (Fig. $8 d, e$ ), which corresponds to the morphology previously described for retinotectal synapses (Hayes and Webster, 1975; Angaut and Reperant, 1976).

\section{Molecules concentrated in retinononrecipient laminae}

Neurofascin. Neurofascin is an immunoglobulin superfamily cell adhesion molecule that belongs to the same subfamily as $\mathrm{Ng}$ CAM/L1 and NrCAM/Bravo (Sonderegger and Rathjen, 1992; Volkmer et al., 1992). At E8 and E10, neurofascin-like immunoreactivity was concentrated in the tectobulbar tract and was also detectable in superficial laminae, as reported previously by 

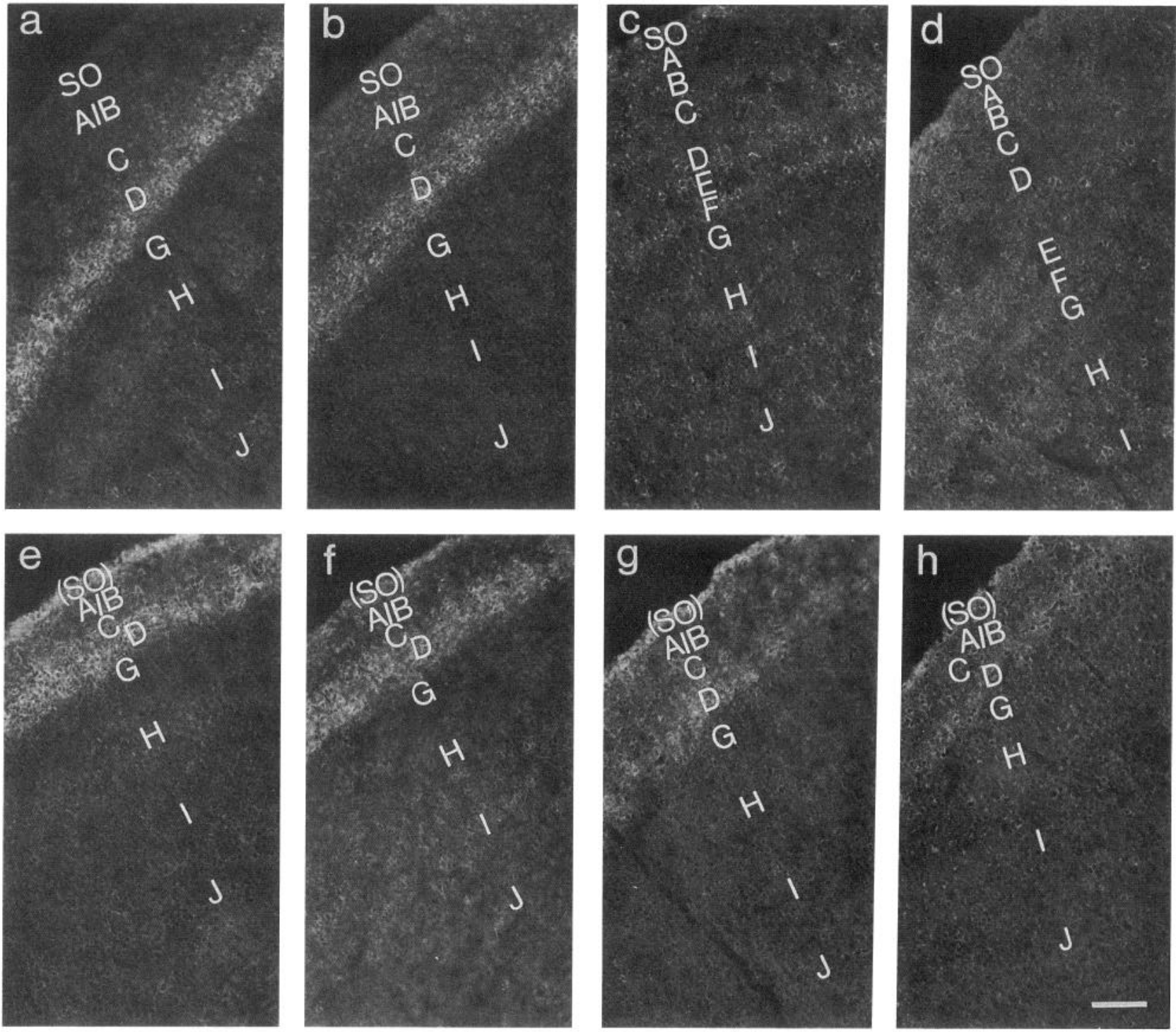

Figure 6. $\mathrm{SC} 1 / \mathrm{JC} 7$ is concentrated in retinorecipient laminae before and after retinal axons arrive. Sections of normal $(a-d)$ or enucleated $(e-h)$ tectum were stained with antibody $\mathrm{JC} 7$ at $\mathrm{E} 12(a, e), \mathrm{E} 14(b, f), \mathrm{E} 16(c, g)$, and E18 tectum $(d, h)$. Bar is $50 \mu \mathrm{m}$.

Kröger and Schwarz (1990). Over the next few days, however, its distribution changed, and neurofascin was localized selectively in the retinononrecipient laminae by the time retinal axons had entered the recipient laminae: it was concentrated in SGFS $\mathrm{H}$ at E12, and in SGFS H-J at E14 (Fig. 9). This staining appeared to be associated with tangentially oriented fibers, and might therefore arise from tangential neurons with somata in SGFS-G or I (LaVail and Cowan, 1971). From E16 onward, weak immunoreactivity was observed throughout all the tectal laminae (not shown). Enucleation had no detectable effect on the distribution of neurofascin (not shown).

Tenascin- $C$. Tenascin- $\mathrm{C}$ is a component of the extracellular matrix that was first identified in muscle (Chiquet and Fambrough, 1984) and later shown to be widely distributed in both neural and non-neural tissues (Erickson, 1993). We detected tenascin- $\mathrm{C}$ with monoclonal antibody $\mathrm{Ml}$, which recognizes the products of all known alternatively spliced tenascin-C mRNAs (Chiquet-Ehrismann et al., 1991). Tenascin-C was widely distributed in the tectum between E8 and E18, as recently described by Perez and Halfter (1993). After hatching, however, the distribution of tenascin-C changed in an intriguing way: its levels decreased in most of the laminae, and it became concentrated in just three laminae, SGFS C, E, and G (Fig. 9b). This pattern is complementary to that of the retinal terminals, which are concentrated in SGFS B, D, and F. A similar pattern emerged in tecta of chicks that were dark reared from hatching (not shown). Enucleation failed to halt the downregulation of tenascin-C levels in most laminae, but no alternating pattern emerged in SGFS, presumably because the laminae themselves did not segregate in enucleated embryos (not shown).

Chondroitin sulfate proteoglycans are ligands of tenascin-C, and their distribution is similar in some parts of the mammalian brain (Crossin et al., 1989; Jhaveri et al., 1991). However, versican, a large mesenchymal proteoglycan thought to be a tenascin-C-binding proteoglycan (Yamagata et al., 1993), was widely distributed in hatchling tectum. Similarly, antibodies to a large cartilage-type proteoglycan, aggrecan, and to chondroitin sulfate chains were widely distributed (Table 2 ). 

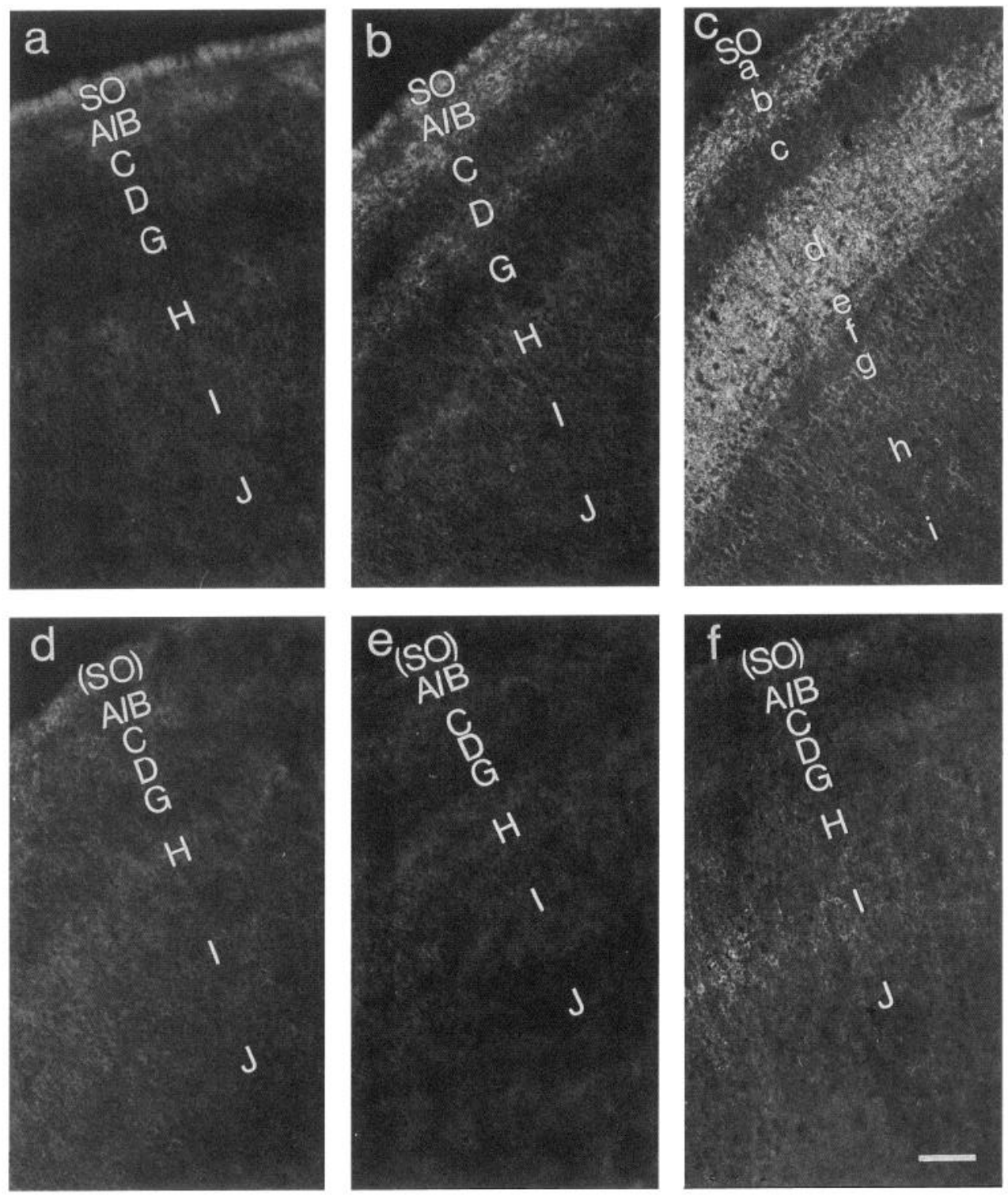

Figure 7. N-cadherin accumulates in retinorecipient laminae as synapses form. Sections of normal $(a-c)$ or enucleated $(d-f)$ tectum were stained with antibody NCD2 to $\mathrm{N}$-cadherin at E12 $(a, d), \mathrm{E} 14(b, e)$, and $\mathrm{P} 2(c, f)$. Bar is $50 \mu \mathrm{m}$.
Sigma antibody. Sigma is an uncharacterized cell surface antigen recognized by a monoclonal antibody that Kayyem et al. (1992) generated using tectal membrane proteins as immunogen. This antibody stained the axial mesenchyme diffusely and intensely, suggesting that it recognizes a component of the extracellular matrix. The distribution of Sigma was similar in many respects to that of tenascin-C: it was widely distributed in tectum at early stages (E10-E16), then became restricted to laminae SGFS C, E, and $\mathrm{G}$ at later stages (Fig. 9c). Moreover, both antigens were downregulated similarly in normal and enucleated embryos (not shown). Despite these similarities, Sigma and tenascin- $\mathrm{C}$ are likely to be distinct antigens. First, Sigma became confined to cellular laminae at E18, when tenascin-C was still widely distributed. Second, Sigma disappeared shortly after hatching, as tenascin- $\mathrm{C}$ was becoming confined to the cellular laminae. Third, Sigma was present on tectal blood vessels, whereas tenascin- $\mathrm{C}$ was not. Finally, Sigma and tenascin-C had distinct distributions in other tissues (not shown).

Molecules not selectively associated with SO or SGFS

Results from all of the antibodies we tested are summarized in Table 2. For convenience, we grouped patterns of expression into seven categories. The first four of these have been described above: molecules concentrated in the SO (pattern A), molecules concentrated in retinorecipient laminae (pattern B), and molecules concentrated at borders of retinorecipient laminae (SGFS G-J, pattern C; and SGFS C, E, and G, pattern D). The majority of antibodies did not stain SO or portions of SGFS selectively, however, but were divisible into three other groups that are described briefly here.

Pattern E. Monoclonal antibodies recognizing laminin (Fig. $10 a$ ), a heparan sulfate proteoglycan (tentatively, perlecan), agrin, and fibronectin stained the external limiting membrane, a basement membrane between the meninges and the SO. When the external limiting membrane and meninges were mechanically removed from the tectum before fixation (Kröger and Niehörster, 1990), these antibodies no longer stained the tectal surface (Fig. 10b), suggesting that their antigens are not directly associated with the tectal parenchyma. Antibodies in this class also stained blood vessels within the tectum. It should be noted that some antibodies to basal lamina components stain mammalian brain faintly or only under specific fixation conditions (e.g., Magill-Solc and McMahan, 1988; Hunter et al., 1992). We 

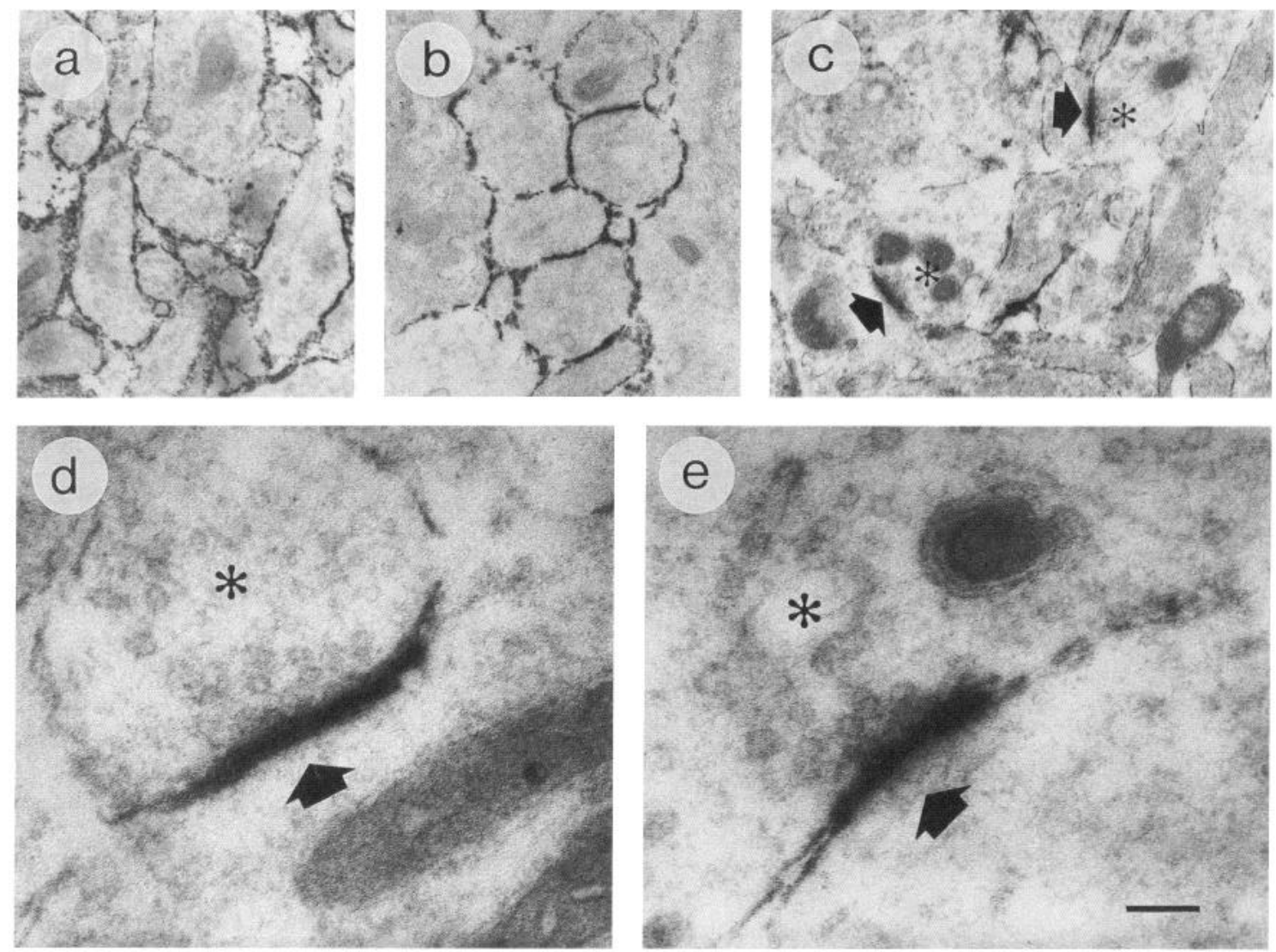

Figure 8. Ultrastructural localization of molecules concentrated in retinorecipient laminae. Electron micrographs of retinorecipient laminae from tecta stained with JC7, a monoclonal antibody to SC1/JC7 (a); VVA-B ${ }_{4}$, a lectin selective for GalNAc residues $(b)$; or NCD2, a monoclonal antibody to the extracellular domain of $\mathrm{N}$-cadherin $(c-e)$. SCl/JC7 and VVA-B -binding glycoconjugates are widely distributed on cellular membranes in retinorecipient laminae, whereas $\mathrm{N}$-cadherin is concentrated in the synaptic cleft. Presynaptic terminals are marked with asterisks and synaptic sites with arrows. $a$, E14, SGFS D; $b$, E14, SGFS D; $c$, E18, SGFS D; $d$, E18, SGFS B; $e$, E18, SGFS D. Bar is $500 \mathrm{~nm}$ for $a-c$, and $100 \mathrm{~nm}$ for $d$ and $e$.
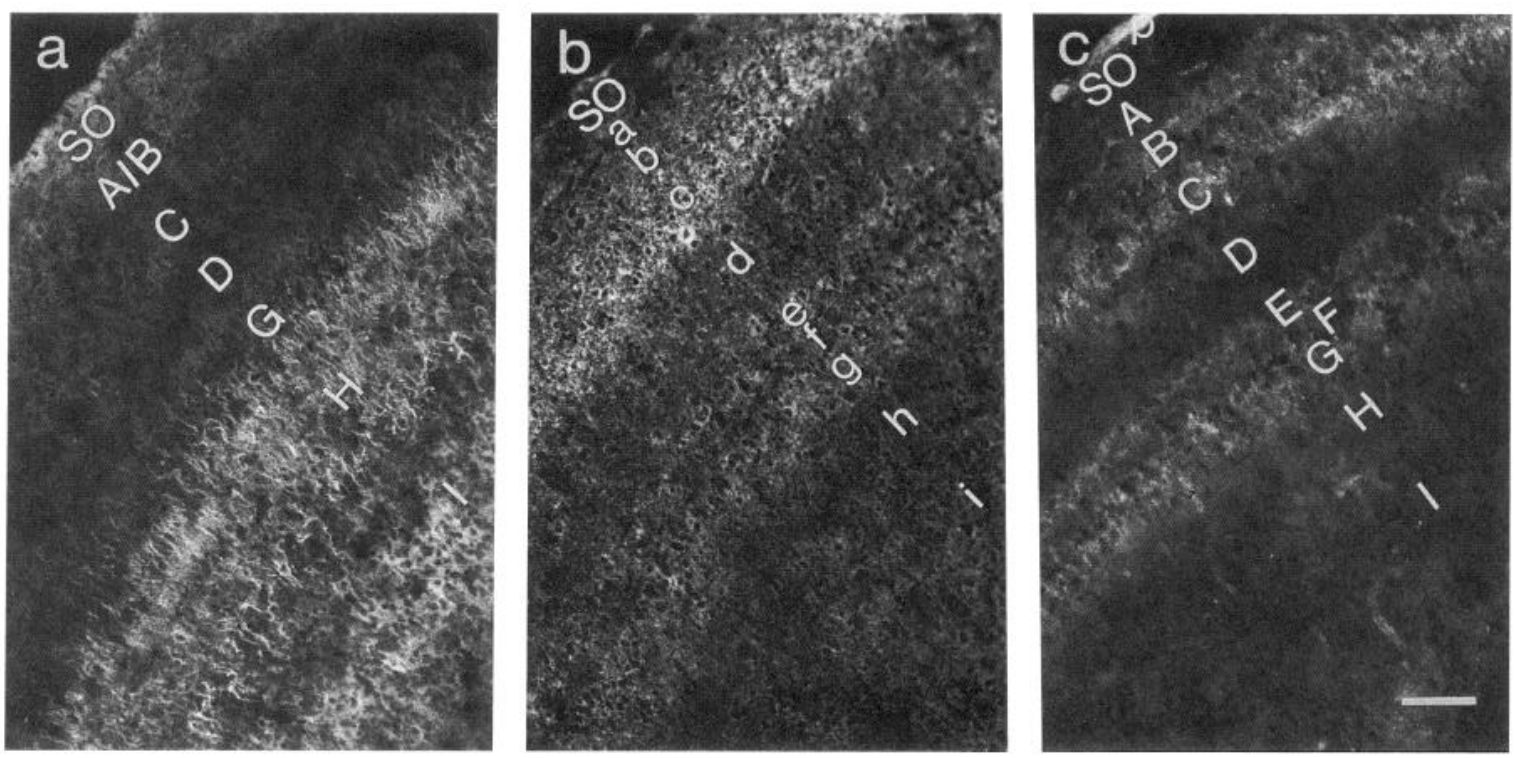

Figure 9. Neurofascin, tenascin-C, and Sigma are concentrated at borders of retinorecipient laminae. $a$, E12 tectum, stained with anti-neurofascin. SGFS-H is selectively stained. $b, \mathrm{P} 2$ tectum stained with anti-tenascin-C. Staining was restricted to the cellular laminae of SGFS. $c$, E1 8 tectum stained with antibody Sigma. Note that the staining is already restricted to the cellular laminae at E18. Bar is $50 \mu \mathrm{m}$. 
Table 2. Localization of cell surface molecules in developing tectum

\begin{tabular}{|c|c|c|c|c|}
\hline \multirow[b]{2}{*}{ Molecule } & \multicolumn{4}{|l|}{ Age } \\
\hline & $\mathrm{E} 12$ & $\mathrm{E} 14$ & $\mathrm{E} 18$ & $\mathrm{P} 2$ \\
\hline N-CAM & $\mathrm{F}$ & $F$ & $\mathrm{~F}$ & $\mathrm{~F}$ \\
\hline $\mathrm{NgCAM} / \mathrm{Ll}$ & A & A & A & - \\
\hline Bravo/NrCAM & $\mathrm{F}$ & $\mathrm{F}$ & $\mathrm{F}$ & - \\
\hline Fll/contactin & $F$ & $\mathrm{~F}$ & $\mathrm{~F}$ & - \\
\hline TAG-1/Axonin-1 & A & A & $\mathrm{G}$ & - \\
\hline Neurofascin & $\mathrm{C}$ & $\mathrm{C}$ & $\mathrm{F}$ & - \\
\hline $\mathrm{SC} 1 / \mathrm{JC} 7$ & $\mathrm{~B}$ & B & $\mathrm{F}$ & $\mathrm{F}$ \\
\hline Neuropilin & $\mathrm{G}$ & B & B & - \\
\hline N-cadherin & $\mathrm{F}$ & B & B & $\mathrm{B}$ \\
\hline L-CAM & $\mathrm{G}$ & G & $\mathrm{G}$ & - \\
\hline Integrin $\beta 1^{\prime \prime}$ & $\mathrm{G}$ & $\mathrm{G}$ & $\mathrm{G}$ & $\mathrm{G}$ \\
\hline$\alpha 5$ & $\mathrm{G}$ & $\mathrm{G}$ & $\mathrm{G}$ & - \\
\hline$\alpha 6$ & $G$ & G & $G$ & - \\
\hline$\alpha 7$ & $G$ & $G$ & $\mathrm{G}$ & - \\
\hline Tenascin-C & $\mathrm{F}$ & $\mathbf{F}$ & $\mathbf{F}$ & $\mathrm{D}$ \\
\hline Heparan sulfate proteoglycan ${ }^{\prime \prime}$ & $\mathrm{E}$ & $\mathrm{E}$ & $\mathrm{E}$ & - \\
\hline Laminin" & $\mathrm{E}$ & $\mathrm{E}$ & $\mathrm{E}$ & $\mathrm{E}$ \\
\hline S-laminin & $\mathrm{G}$ & $\mathrm{G}$ & $\mathrm{G}$ & - \\
\hline Agrin $\alpha$ & $\mathrm{E}$ & $\mathrm{E}$ & $\mathrm{E}$ & $\mathrm{E}$ \\
\hline Fibronectint & $\mathrm{E}$ & $\mathrm{E}$ & $\mathrm{E}$ & - \\
\hline Versican & $\mathrm{F}^{\prime}$ & $\mathrm{F}^{\prime \prime}$ & $\mathrm{F}$ & $\mathrm{F}$ \\
\hline Aggrecan & $F^{\prime \prime}$ & $F^{\prime \prime}$ & $\mathrm{F}$ & - \\
\hline Sigma & $\mathrm{F}$ & $F$ & $\mathrm{D}$ & $\mathrm{G}$ \\
\hline Thrombospondin & $\mathrm{F}$ & $\mathrm{F}$ & $\mathrm{F}$ & - \\
\hline Chondroitin sulfate & $\mathrm{F}$ & $\mathrm{F}$ & $\mathrm{F}$ & $\mathrm{F}$ \\
\hline Keratan sulfate & $\mathrm{F}$ & $\mathrm{F}$ & $\mathrm{F}$ & - \\
\hline L2/HNK 1 & $\mathrm{~F}$ & $\mathrm{~F}$ & $F$ & - \\
\hline $\mathrm{L}_{3}$ & G & $\mathbf{G}^{\prime}$ & $\mathbf{G}$ & - \\
\hline VVA-B, lectin & $\mathrm{B}$ & $\mathrm{B}$ & $\mathrm{B}$ & $\mathrm{B}^{\prime \prime}$ \\
\hline Polysialic acid & $\mathrm{B}$ & $\mathrm{G}$ & G & - \\
\hline Ganglioside 8A2 & $\mathrm{F}$ & $F$ & $F$ & - \\
\hline
\end{tabular}

Staining patterns are summarized in Figure 11 , and explained in the text. Briefly, pattern $\mathrm{A}=$ concentrated in the $\mathrm{SO} ; \mathrm{B}=$ concentrated in tetinorecipient laminae: $C$ and $D=$ concentrated at borders of retinorecipient laminae; $E=$ restricted to basal laminae: $F=$ widespread distribution in many laminae: $G$ $=$ present at low levels or undetectable.

"Blood vessels were stained.

"SGFS A-I were less intensely stained than other laminae.

SGFS and SO were faintly stained.

- not done. Data on neuropilin are from Fujisawa, Takagi, and Yamagata (unpublished results)

cannot, therefore, exclude the possibility that some of the antigens in this group might be detectable in tectum under other conditions.

Pattern $F$. This category is the most heterogeneous, and includes a variety of antibodies that stained tecta but showed no markedly lamina-specific distribution. For example, versican, a large chondroitin sulfate proteoglycan, was present at high levels in SO, SGFS I and J, SGC, and SAC, but was also detectable at lower levels in SGFS B-G (Fig. 10c).

Pattern $G$. All antibodies in this category were shown to be active in our hands, but they stained the tectum faintly if at all. For example, anti-s-laminin stained pial blood vessels, external to the tecturn, but did not stain either the tectal neuropil or the external limiting membrane (Fig. $10 d$ ).

\section{Discussion}

The aim of this study was to describe the adhesive landscape that retinal axons encounter when they enter the developing optic tectum. We hoped thereby to identify molecules or structures that might guide retinal axons to their appropriate laminar destinations. Figure 11 juxtaposes the intratectal territory of retinal axons (Acheson et al., 1980) and the laminar distribution of several cell surface components (documented above) with a hypothetical model of guidance cues, based on our recent study of retinotectal cocultures (Yamagata and Sanes, 1995). In the following sections, we consider what our immunohistochemical investigation has taught us about axonal guidance in the tectum.

\section{Cues for axon extension in the SO}

An intriguing structure in the SO is the fine layer of fasciculated fibers that is present before retinal axons arrive and that persists in enucleated tecta. These fibers, which run perpendicular to the retinal axons, are present at an appropriate time and place to promote ingrowth of retinal axons through the SO and/or branching of retinal axons into deeper layers. They may bear a variety of adhesion molecules, including N-CAM, neurofascin, contactin, $\mathrm{N}$-cadherin, $\mathrm{NgCAM} / \mathrm{Ll}$, and $\mathrm{SCl} / \mathrm{JC} 7$, but their most prominent component is axonin-1/TAG-1. NgCAM/L1, which is abundant on the ingrowing retinal axons, is a homophilic adhesion molecule but can also bind heterophilically to axonin/ TAG-1 (Kuhn et al., 1991; Felsenson et al., 1994), N-CAM (Kadmon et al., 1990), and contactin (Brummendorf et al., 1993). Similarly, TAG-1 can mediate adhesion homophilically, but neurite outgrowth on TAG-I requires an L I-like molecule (Felsenfeld et al., 1994). Therefore, we suggest that axonin-1/ TAG-1 plays a role in promoting the ingrowth of the first-arriving retinal axons through the $\mathrm{SO}$. At later stages, these libers either disappear or lose their complement of axonin-1/TAG-1. Thus, axonin/TAG-1-positive fibers are reminiscent of transient tracts that guide later-arriving axons in other systems (e.g., the cortical subplate; Allendoerfer and Shatz, 1994).

Later stages of ingrowth may depend on other cues. In vitro, purified $\mathrm{NgCAM} / \mathrm{LI}$ promotes outgrowth of retinal axons (Kröger and Walter, 1990), and retinal outgrowth along the SO is diminished (but not abolished) by enucleation. Therefore, homophilic interactions of $\mathrm{Ng}-\mathrm{CAM} / \mathrm{Ll}$ as well as N-CAM (Thanos et al., 1984) may promote the fasciculated outgrowth of follower axons. In addition, interactions with the basal lamina may also guide retinal ingrowth. Components of the extracellular matrix promote growth of retinal axons in vitro via integrin-dependent mechanisms (Cohen et al., 1986; Hall et al., 1987). However, two lines of evidence suggest that the basal lamina is inessential for guidance in the SO. First, retinal axons appear to invade the SO through the tectal plate rather than from the pial surface (Fig. $2 a$ ). Second, retinal axons extend through the SO of tectal slices from which the overlying basal laminae had been removed (Yamagata and Sanes, 1995). Thus, although laminin-rich substrata may be important for guiding retinal axons through the optic nerve and tract (Hynes and Lander, 1992), they seem likely to play only a subsidiary role within the tectum itself.

\section{Cues for arborization in retinorecipient laminae}

Between E10 and E12, retinal axons leave the SO and form broad, apparently transitory arbors in the uppermost portion of SGFS. Between E12 and E16, these arbors are remodeled or replaced by definitive arbors in SGFS A/B, D, and F (Fig, 1). A major finding of our study is that several molecules-poly- 

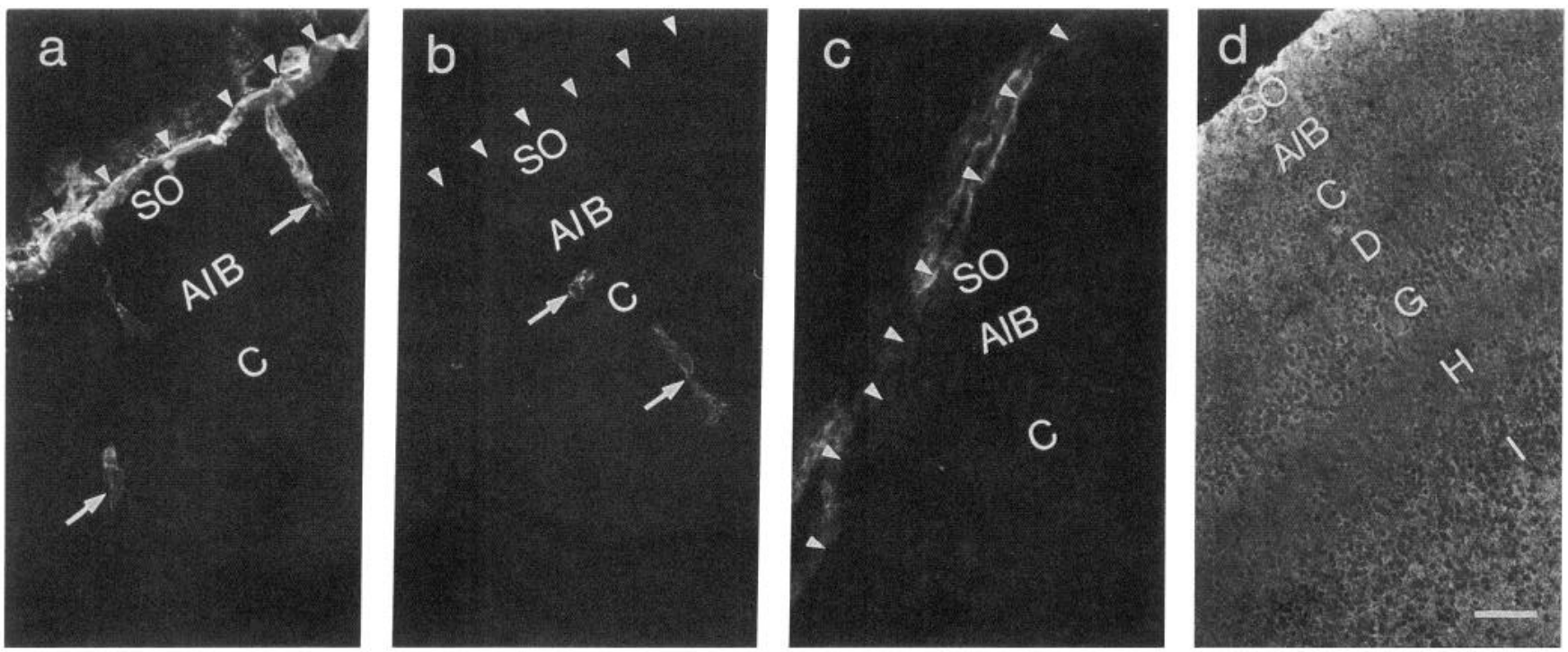

Figure 10. Extracellular matrix of the optic tectum at E14. Sections of E14 tectum were stained with antibodies to $(a, b)$ laminin, $(c)$ s-laminin, or $(d)$ versican. $b$ is from a tectum that had been stripped of its meninges before fixation, to remove the external limiting membrane. Laminin is confined to blood vessels (arrows) and the external limiting membrane (pattern E in Table 2). Tectal surface is marked with arrowheads in $a-c$. Bar is $60 \mu \mathrm{m}$ for $a-c$, and $50 \mu \mathrm{m}$ for $d$.

sialylated N-CAM, SC1/JC7, N-cadherin, and VVA-B -binding $^{-}$ glycoconjugates-are selectively associated with retinorecipient laminae during some or all of this period. Differences in their temporal patterns of expression divide them into three classes.

First, polysialylated N-CAM is concentrated in the retinorecipient laminae on E10-E12, a period during which growth within the SO predominates and initial branching out of the SO occurs. N-CAM is still present but no longer detectably polysi- alylated by E14, as the axons begin to form their definitive arbors. Polysialylation weakens the homophilic bonds between $\mathrm{N}$-CAM molecules, and the presence of polysialylated N-CAM also decreases adhesion mediated by other molecules, including $\mathrm{NgCAM} / \mathrm{Ll}$ (Rutishauser, 1992). The outgrowth of neurites from retinal ganglion cells is decreased by removal of polysialic acid from their substrate (Doherty et al., 1990; Zhang et al., 1992), suggesting that polysialylation of the retinorecipient laminae

\section{a) RETINAL INPUTS}

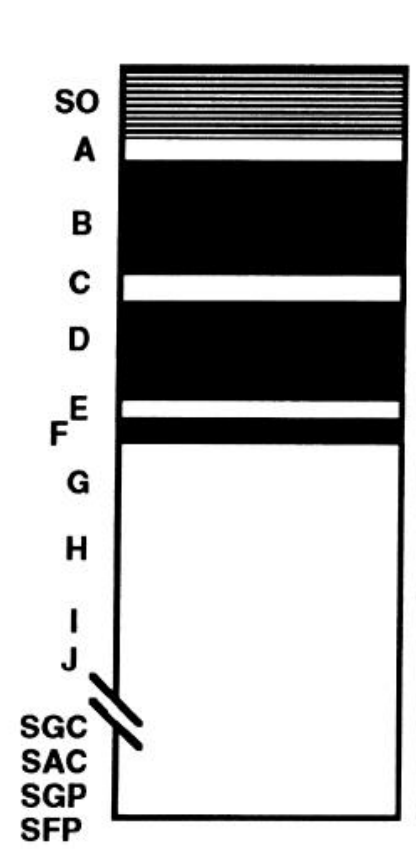

b) CUES

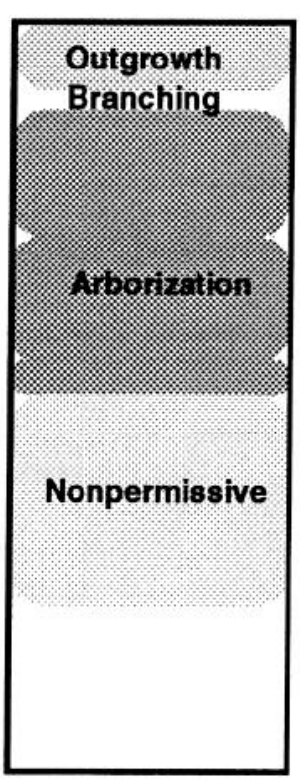

c) ADHESIVE TOPOGRAPHY

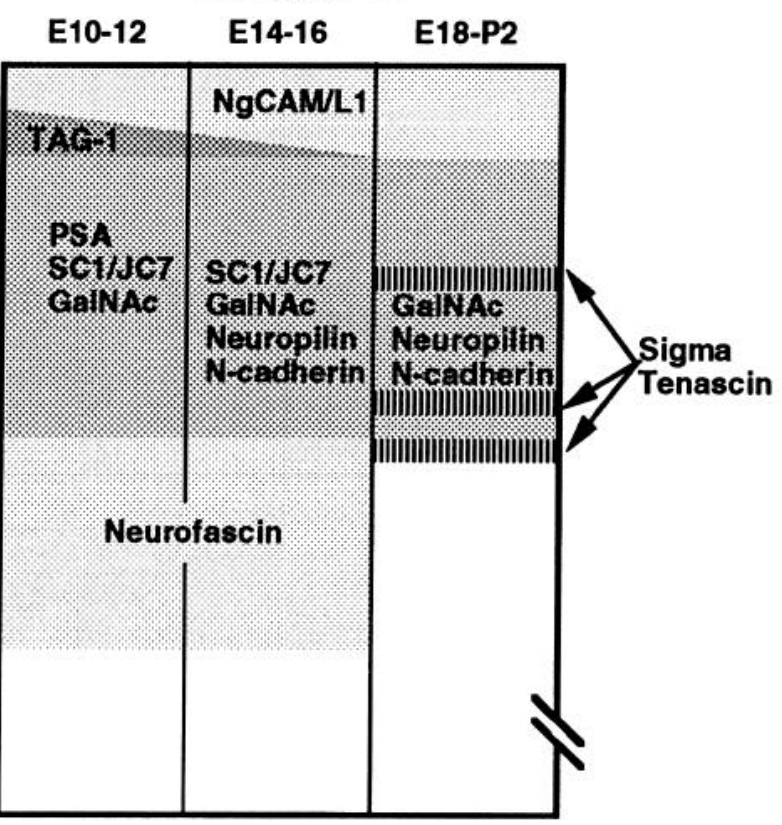

Figure 11. Adhesive topography of optic tectum. $a$, Retinal axons run through the SO, and terminate in SGFS B, D, and F. $b$, Hypothetical distributions of cues that direct ingrowth, branching, and arborization of retinal axons (from Yamagata and Sanes, 1995). $c$, Laminar distribution of adhesive macromolecules that might provide signals to retinal axons. See text for details. 
helps to provide a favorable terrain for axonal branching. How ever, the presence of polysialic acid prior to axonal branching, and its loss by the time arborization is maximal, raises the alternate possibility that polysialic acid inhibits growth-promoting cues from acting prematurely. The availability of a highly specific endoneuraminidase that removes polysialic acid in ovo (Landmesser et al., 1990; Tang et al., 1992) should allow us to test these alternatives.

Second, SCl/JC7 and $\mathrm{VVA}_{-} \mathrm{B}_{4}$-binding glycoconjugates are highly concentrated in retinorecipient laminae hefore and during the period when retinal axons form their definitive arbors. These two molecules appear on schedule in enucleated tecta, although we cannot exclude the possibility that they are present on retinal axons as well as on tectal membranes. Interestingly, electron microscopy showed that both $\mathrm{SCl} / \mathrm{JC} 7$ and $\mathrm{VVA}_{4}-\mathrm{B}_{4}$-binding carbohydrates are present on many if not most cell surfaces in the retinorecipient laminae. This distribution raises the question of which cells synthesize these components: they might be produced by many cell types within the laminae, or by a particularly abundant cell type (e.g., astrocytes), or they might be able to diffuse some distance from their sites of synthesis. In any event, the localization of these molecules suggests that they could mediate target recognition, arborization, or synapse formation by retinal axons.

Another possible member of this group is neuropilin, previously called the A5 antigen. Takagi et al. (1987, 1991) initially showed that this neurite outgrowth - promoting cell surface molecule is concentrated in the retinorecipient laminae of Xenopus laevis optic tectum. More recently, these workers have cloned a chicken homolog of neuropilin, and shown that it is localized to SGFS D in both nomal and enucleated tecta (S. Takagi and $H$. Fujisawa, personal communication; H. Fujisawa and M. Yamagata, unpublished observations).

Finally, N-cadherin accumulates in retinorecipient laminae as retinal arborizations are forming. Electron microscopy showed it to be present in the synaptic cleft, and enucleation prevented its accumulation in retinorecipient laminae. Its late appearance, subcellular localization, and dependence on retinal input are inconsistent with a role for $\mathrm{N}$-cadherin in axonal targeting or arbor formation in this system. Instead, these observations all support the idea that $\mathrm{N}$-cadherin contributes to the adhesion of pre- to postsynaptic membranes at retinotectal synapses. Although involvement of $\mathrm{N}$-cadherin in synapse formation per se has not, to our knowledge, been tested in any system, it is noteworthy that members of the cadherin family have been implicated in the formation of other intercellular junctions, including adherence junctions and desmosomes (Takeichi, 1990; Buxton and Magee, 1992).

\section{Cues that confine axons to retinorecipient laminae}

The restriction of retinal arbors to retinorecipient laminae may reflect a combination of the favorable terrain in these laminae and inhibitory influences at their borders. In vivo, retinal axons never penetrate past SGFS F (Fig. 2), and in vitro, retinal axons grow poorly on laminae directly beneath SGFS F (Yamagata and Sanes, 1995). These observations led us to suggest the existence of a nonpermissive substrate in the deep portions of SGFS. In the present study, we show that neurofascin is present in the areas that we had supposed to be nonpermissive, raising the possibility that this immunoglobulin superfamily molecule is a repellent cue for retinal axons. At present, no counter-receptors of neurofascin have been described, and there is no evidence that neurofascin can inhibit neurite outgrowth (F. Rathjen, personal communication). However, another immunoglobulin superfamily molecule, contactin, is known to mediate repulsive interactions (Pesheva et al., 1993).

Finally, two molecules, tenascin-C and Sigma, are widely distributed at low levels at early stages, but become concentrated at the borders of retinorecipient laminae late in development. These distributions are reminiscent of those seen in the mannmalian somatosensory cortex. In this area, thalamic input is focused in the centers of small domains called barrels, and tenascin- $\mathrm{C}$ is distributed around each barrel's periphery (Crossin et al., 1989; Steindler et al., 1989; Schlaggar and O'Leary, 1993). Based on this pattern, and on the known ability of tenascin-C to inhibit neurite outgrowth (Edelman, 1992), is has been suggested that this molecule serves to prevent thalamic arbors from sprouting beyond the confines of their barrels. It was recently shown that tenascin- $\mathrm{C}$ is a repellent molecule for chick retinal axons (Peres and Halfter, 1993), suggesting that tenascin- $\mathrm{C}$ may perform the similar function of confining retinal arbors to appropriate tectal laminae.

\section{References}

Acheson DWK, Kemplay SK, Webster KE (1980) Quantitative analysis of optic terminal profile distribution within the pigeon optic tectum. Neuroscience 5:1067-1084.

Allendoerfer KL, Shatz CJ (1994) The subplate, a transient neocortical structure: its role in the development of connections between thalamus and cortex. Annu Rev Neurosci 17:185-218.

Angaut P, Repérant J (1976) Fine structure of the optic fibre termination layers in the pigeon optic tectum: a Golgi and electron microscope study. Neuroscience 1:93-105.

Avnur Z, Geiger B (1984) Immunocytochemical localization of native chondroitin-sulfate in tissues and cultured cells using specilic monoclonal antibody. Cell 38:811-822.

Bao ZZ, Lakonishok M, Horwitz AF (1993) The $\alpha 7 \beta 1$ integrin is a component of the myotendinous junction on skeletal muscle. J Cell Sci 106:579-589.

Bayer SA, Altman J (1987) Directions in neurogenetic gradients and patterns of anatomical connections in the telencephalon. Prog Neurobiol 29:57-106.

Bayne EK. Anderson MJ, Fambrough DM (1984) Extracellular matrix organization in developing muscle: correlation with acelylcholine receptor aggregates. J Cell Biol 99:1486-1501.

Bolz J, Götz M, Hubener M, Novak N (1993) Reconstructing cortical connections in a dish. Trends Neurosci 16:310-316.

Bronner-Fraser M, Lallier T (1988) A monoclonal antibody against a laminin-heparan sulfate proteoglycan complex perturbs cranial neural crest migration in vivo. J Cell Biol 106 1321-1329.

Bronner-Fraser M, Artinger M, Muschler J. Horwitz AF (1992) Developmentally regulated expression of $\alpha 6$ integrin in avian embryos. Development 115:197-211.

Brummendorf T, Hubert M. Treubert U, Leuschner R. Tarnok A, Rathjen FG (1993) The axonal recognition molecule Fll is a multifunctional protein: specific domains mediate interactions with $\mathrm{Ng}-$ CAM and restrictin. Neuron 10:711-727.

Burgoon MP, Grumet M, Mauro V, Edelman GM, Cunningham BA (1991) Structure of the chicken neuron-glia cell adhesion molecule, $\mathrm{Ng}-\mathrm{CAM}$ : origin of the polypeptides and relation to the Ig superfamily. J Cell Biol 112:1017-1029.

Burns FR, von Kannen S, Guy L, Raper JA, Kamhol/ J, Chang S (1991) DM-GRASP, a novel immunoglobulin superfamily axonal su1face protein that supports neurite extension. Neuron 7:209-220.

Buxton RS, Magee AI (1992) Structure and interactions of desmosomal and other cadherins. Semin Cell Biol 3:157-167.

Caterson B, Christner JE, Baker JR (1983) Identification of a monoclonal antibody that specifically recognizes corneal and skeletal keratan sulfate. Monoclonal antibodies to cartilage proteoglycan. J Biol Chem 258:8848-8854.

Celio MR (1993) Perineuronal nets of extracellular matrix around parvalbumin-containing neurons of the hippocampus. Hippocampus 3:55-60. 
Chang S, Rathjen FG, Raper JA (1987) Extension of neurites on axons is impaired by antibodies against specific neural cell surface glycoproteins. J Cell Biol 104:355-362.

Chang S, Rathjen FG, Raper JA (1990) Neurite outgrowth promoting activity of G4 and its inhibition by monoclonal antibodies. J Neurosci Res 25:180-186.

Chiquet M, Fambrough DM (1984) Chick myotendinous antigen. I. A monoclonal antibody as a marker for tendon and muscle morphogenesis. J Cell Biol 98:1926-1936.

Chiquet-Ehrismann R, Matsuoka Y, Hofer U, Spring J, Bernasconi C, Chiquet M (1991) Tenascin variants: differential binding to fibronectin and distinct distribution in cell cultures and tissues. Cell Reg 2:927-938.

Cifuentes-Diaz C, Nicolet M, Goudou D, Rieger F, Mege RM (1994) $\mathrm{N}$-cadherin expression in developing, adult and denervated chicken neuromuscular system: accumulations at both the neuromuscular junction and the node of Ranvier. Development 120:1-11.

Cohen J, Burne JF, Winter J, Bartlett P (1986) Retinal ganglion cells lose response to laminin with maturation. Nature $322: 465-467$.

Constantine-Paton PM, Cline HT, Debski E (1990) Patterned activity, synaptic convergence, and the NMDA receptor in developing visual pathways. Annu Rev Neurosci 13:129-154.

Cremer H, Lange R, Christoph A, Plomann M, Vopper G, Roes J, Brown R, Baldwin S, Kraemer P, Scheff S, et al. (1994) Inactivation of the N-CAM gene in mice results in size reduction of the olfactory bulb and deficits in spatial learning. Nature 367:455-459.

Crossin KL, Hoffman S, Tan SS, Edelman GM (1989) Cytotactin and its proteoglycan ligand mark structural and functional boundaries in somatosensory cortex of the early postnatal mouse. Dev Biol 136: 381-392.

de la Rosa EJ, Kayyem JF, Roman JM, Stierhof Y-D, Dreyer WJ, Schwarz U (1990) Topologically restricted appearance in the developing chick retinotectal system of Bravo, a neural surface protein: experimental modulation by environmental cues. J Cell Biol 111: 3087-3096.

Dodd J, Morton SB, Karagogeos D, Yamamoto M, Jessell TM (1988) Spatial regulation of axonal glycoprotein expression on subsets of embryonic spinal neurons. Neuron 1:105-116.

Doherty P, Cohen N, Walsh FS (1991) Neurite outgrowth in response to transfected N-CAM changes during development and is modulated by polysialic acid. Neuron 5:209-219.

Drazba J, Lemmon V (1990) The role of cell adhesion molecules in neurite outgrowth on Muller cells. Dev Biol 138:82-93.

Drazba J, Pierce M, Lemmon V (1991) Studies of the developing chick retina using monoclonal antibody $8 \mathrm{~A} 2$ that recognizes a novel set of gangliosides. Dev Biol 145:154-163.

Edelman GM (1992) Mediation and inhibition of cell adhesion by morphoregulatory molecules. Cold Spring Harbor Symp Quant Biol 57: 317-325.

El-Deeb S, Thompson SC, Covault J (1992) Characterization of a cell surface adhesion molecule expressed by a subset of developing chick neurons. Dev Biol 149:213-227.

Erickson HP (1993) Tenascin-C, tenascin-R and tenascin-X: a family of talented proteins in search of functions. Curr Opin Cell Biol $5: 869-876$

Felsenfeld DP, Hynes MA, Skoler KM, Furley AJ, Jessell TM (1994) T $\Lambda$ G-1 can mediate homophilic binding, but neurite outgrowth on TAG-1 requires an L1-like molecule and $\beta 1$ integrins. Neuron 12: $675-690$.

Fraser SE, Carhart MS, Murray BA, Chuong CM, Edelman GM (1988) Alterations in the Xenopus retinotectal projection by antibodies to Xenopus N-CAM. Dev Biol 129:217-230.

Galileo DS, Majors J, Horwitz AF, Sanes JR (1992) Retrovirally introduced antisense integrin RNA inhibits neuroblast migration in vivo. Neuron 9:1117-1131.

Gallin WJ, Edelman GM, Cunningham BA (1983) Characterization of L-CAM, a major cell adhesion molecule from embryonic liver cells. Proc Natl Acad Sci USA 80:1038-1042.

Gardner JM, Fambrough DM (1983) Fibronectin expression during myogenesis. J Cell Biol 96:474-485.

Godfrey EW, Siebenlist RE, Wallskog PA, Walters LM, Bolender DL, Yorde DE (1988) Basal lamina components are concentrated in premuscle masses and at early acetylcholine receptor clusters in chick embryo hindlimb muscles. Dev Biol 130:471-486.

Goodman CS, Shatz CJ (1993) Developmental mechanisms that gen- erate precise patterns of neuronal connectivity, Cell 72/Neuron 10: $77-98$.

Greve JM, Gottlieb DI (1982) Monoclonal antibodies which alter the morphology of cultured chick myogenic cells. J Cell Biochem 18: 221-229.

Halfter W (1993) A heparan sulfate proteoglycan in developing avian axonal tracts. J Neurosci 13:2863-2873.

Halfter W, Yip Y-PL, Yip JW (1994) Axonin 1 is expressed primarily in subclasses of avian sensory neurons during outgrowth. Dev Brain Res 78:87-101.

Hall DE, Neugebauer KM, Reichardt LF (1987) Embryonic neural retinal cell response to extracellular matrix proteins: developmental changes and effects of the cell substratum attachment antibody (CSAT). J Cell Biol 104:623-634.

Hamburger V, Hamilton HL (1951) A series of normal stages in the development of the chick embryo. J Morphol 88:49-92.

Hatta K, Takagi S, Fujisawa H, Takeichi M (1987) Spatial and temporal expression pattern of $\mathrm{N}$-cadherin cell adhesion molecules correlated with morphogenetic processes of chicken embryos. Dev Biol 120 $215-227$.

Haycs BP, Webster KE (1975) An electron microscope study of the retino-receptive layers of the pigeon optic tectum. J Comp Neurol 162:447-466.

Huber GC, Crosby EC (1933) A phylogenetic consideration of the optic tectum. Proc Natl Acad Sci USA 19:15-22.

Hunt SP, Brecha N (1984) The avian optic tectum: a synthesis of morphology and biochemistry. In: Comparative neurology of the optic tectum (Vanegas H, ed), pp 619-648. New York: Plenum.

Hynes RO, Lander AD (1992) Contact and adhesive specificities in the associations, migrations, and targeting of cells and axons. Cell 68 : 303-322

Ichimura T, Hashimoto PH (1988) Structural components in the synaptic cleft captured by freeze-substitution and deep etching of directly frozen cerebellar cortex. J Neurocytol 17:3-12.

Kadmon G, Kowitz A, Altevogt P, Schachner M (1990) The neural cell adhesion molecule $\mathrm{N}$-CAM enhances $\mathrm{L} 1$-dependent cell-cell interactions. J Cell Biol 110:193-208.

Katz LC, Callaway EM (1992) Development of local circuits in mammalian visual cortex. Annu Rev Neurosci 15:31-56.

Kayyem JF, Roman JM, Von Boxberg Y, Schwarz U, Dreyer WJ (1992) $A$ method for the generation of monoclonal antibodies against rare cell-surface molecules. Eur J Biochem 208:1-8.

Kelly JP, Cowan WM (1972) Studies on the development of the chick optic tectum. III. Effects of early eye removal. Brain Res 42:263288

Kröger S, Niehörster L (1990) Isolation, characterization, and substrate properties of the external limiting membrane from the avian embryonic optic tectum. J Neurosci Res 27:169-183.

Kröger S, Schwarz U (1990) The avian tectobulbar tract: development, explant culture, and effects of antibodies on the pattern of neurite outgrowth. J Neurosci 10:3118-3134.

Kröger S, Walter J (1991) Molecular mechanisms separating two axonal pathways during embryonic development of the avian optic tectum. Neuron 6:291-303.

Kruse J, Mailhammer R, Wernecke H, Faissner A, Sommer I, Goridis C, Schachner M (1984) Neural cell adhesion molecules and myelinassociated glycoprotein share a common carbohydrate moicty recognized by monoclonal antibodies L2 and HNK-1. Nature 311:153155.

Krushel LA, Prieto AL, Cunningham BA, Edelman GM (1993) Expression patterns of the cell adhesion molecule Nr-CAM during histogenesis of the chick nervous system. Neuroscience 53:797-812.

Kücherer A, Faissner A, Schachner M (1987) The novel carbohydrate epitope L 3 is shared by some neural cell adhesion molecules. J Cell Biol 104:1597-1602.

Kuhn TB, Stoeckli ET, Condrau MA, Rathjen FG, Sonderegger P (1991) Neurite outgrowth on immobilized axonin-1 is mediated by a heterophilic interaction with L1(G4). J Cell Biol 115:1113-1126.

Lapper SR, Bolam JP (1991) The anterograde and retrograde transport of neurobiotin in the central nervous system of the rat: comparison with biocytin. J Neurosci Methods 39:163-174.

Lagunowich LA, Schneider JC, Chasen S, Grunwald GB (1992) Immunohistochemical and biochemical analysis of N-cadherin expression during CNS development. J Neurosci Res 32:202-208.

Lakonishok M, Muschler J, Horwitz AF (1992) The $\alpha 5 \beta 1$ integrin 
associates with a dystrophin containing lattice during muscle development. Dev Biol 152:209-220.

Landmesser L, Dahm L, Tang JC, Rutishauser U (1990) Polysialic acid as a regulator of intramuscular nerve branching during embryonic development. Neuron 4:655-667.

LaVail JH, Cowan WM (1971) The development of the chick optic tectum. I. Normal morphology and cytoarchitectonic development. Brain Res 28:391-419.

Lagenaur C, Lemmon V (1987) An Ll-like molecule, the 8D9 antigen, is a potent substrate for neurite extension. Proc Natl Acad Sci USA $84: 7753-7757$

Lemmon V, McLoon SC (1986) The appearance of an L1-like molecule in chick primary visual pathway. J Neurosci 6:2987-2994.

Lemmon V. Staros EB, Perry HE, Gottlieb DI (1982) A monoclonal antibody which binds to the surface of chick brain cells and myotubes: cell selectivity and properties of the antigen. Dev Brain Res $3: 349-360$

Magill-Solc C, McMahan UJ (1988) Motor neurons contain agrin-like molecules. J Cell Biol 107:1825-1833.

Matsunaga M, Hatta K, Nagafuchi A. Takeichi M (1988) Guidance of optic nerve fibres by $\mathrm{N}$-cadherin adhesion molecules. Nature 334:6264.

McLoon SC (1985) Evidence for shifting connections during development of the chick retinotectal projection. J Neurosci 5:2570-2580.

Mey J, Thanos S (1992) Development of the visual system of the chick-a review. J Hirnforsch 33:673-702.

Nakamura H, O'Leary DDM (1989) Inaccuracies in initial growth and arborization of chick retinotectal axons followed by course corrections and axon remodeling to develop topographic order. J Neurosci 9:3776-3795

Neugebauer KM, Tomaselli KJ, Lilien J, Reichardt LF (1988) N-cadherin, NCAM, and integrins promote retinal neurite outgrowth on astrocytes in vitro. J Cell Biol 107:1177-1187.

Paschke KA, Lottspeich F, Stuermer CA (1992) Neurolin, a cell surface glycoprotein on growing retinal axons in the goldfish visual system, is reexpressed during retinal axonal regeneration. J Cell Biol 117: $863-875$

Perez RG. Halfter W (1993) Tenascin in the developing chick visual system: distribution and potential role as a modulator of retinal axon growth. Dev Biol 156:278-292.

Pesheva P, Gennarini G, Goridis C, Schachner M (1993) The F3/11 cell adhesion molecule mediates the repulsion of neurons by the extracellular matrix glycoprotein J1-160/180. Neuron 10:69-82.

Piller V, Piller F, Cartron J-P (1990) Comparison of the carbohydratebinding specificities of seven $N$-acetyl-D-galactosamine-recognizing lectins. Eur J Biochem 191:461-466.

Pollerberg EG, Sadoul R, Goridis C, Schachner M (1985) Selective expression of the 180-kD component of the neural cell adhesion molecule N-CAM during development. J Cell Biol 101:1921-1929.

Pourquié O, Corbel C, Le Caer J-P, Rossier J, Le Douarin NM (1992a) BEN, a surface glycoprotein of the immunoglobulin superfamily, is expressed in a variety of developing systems. Proc Natl Acad Sci USA 89:5261-5265

Pourquié O, Hallonet MER, Le Douarin NM (1992b) Association of BEN glycoprotein expression with climbing fiber axogenesis in the avian cerebellum. J Neurosci 12:1548-1557.

Ramón y Cajal S (1911) Histologie du systeme nerveux de l'homme et des vertebres, Vol 2. Paris: Maloine.

Rathjen FG, Wolff JM, Chang S, Bonhoeffer F, Raper JA (1987) Neurofascin: a novel chick cell-surface glycoprotein involved in neuriteneurite interactions. Cell 51:841-849.

Redies C, Engelhart K, Takeichi M (1993) Differential expression of $\mathrm{N}$ - and $\mathrm{R}$-cadherin in functional neuronal systems and other structures of the developing chicken brain. J Comp Neurol 333:398-416.

Rutishauser U (1992) NCAM and its polysialic acid moiety: a mechanism for pull/push regulation of cell interactions during development? Development [Suppl]:99-104.

Sanes JR (1993) Basement membrane molecules in vertebrate nervous system. In: Molecular and cellular aspects of basement membranes (Timpl R, Rohrbach H, eds), pp 67-87. New York: Academic.

Sanes JR, Cheney JM (1982) Lectin binding reveals a synapse-specific carbohydrate in skeletal muscle. Nature 300:646-647.

Schlaggar BL, O'Leary DDM (1993) Patterning of the barrel field in somatosensory cortex with implications for the specification of neocortical areas. Perspect Dev Neurobiol 1:81-91.

Scott LJC, Bacou F, Sanes JR (1988) A synapse-specific carbohydrate at the neuromuscular junction: association with both acetylcholinesterase and a glycolipid. J Neurosci 8:932 944.

Sonderegger P, Rathjen FG (1992) Regulation of axonal growth in the vertebrate nervous system by interactions between glycoproteins belonging to two subgroups of the immunoglobulin superfamily. J Cell Biol 119:1387-1394.

Steindler DA, Cooper NG, Faissner A, Schachner M (1989) Boundaries defined by adhesion molecules during development of the cerebral cortex: the $\mathrm{J} /$ tenascin glycoprotein in the mouse somatosensory cortical barrel field. Dev Biol 131:243-260.

Takagi S, Tsuji T, Amagai T, Takamatsu T, Fujisawa H (1987) Specific cell surface labels in the visual centers of Xenopus laevis tadpole identified using monoclonal antibodies. Dev Biol 122:90-100.

Takagi S, Hirata T, Agata K, Mochii M. Eguchi G, Fujisawa H (1991) The A5 antigen, a candidate for the neural recognition molecule, has homologies to complement components and coagulation factors. Neuron $7: 295-307$.

Takeichi M (1990) Cadherins: a molecular family important in selective cell-cell adhesion. Annu Rev Biochem 59:237-252.

Tanaka H, Matsui T, Agata A, Tomura M, Kubota I. McFarland KC, Kohr B, Lee A, Phillips HS, Shelton DL (1991) Molecular cloning and expression of a novel adhesion molecule, SC1. Neuron 7:535545 .

Tang J, Landmesser L, Rutishauser U (1992) Polysialic acid influences specific pathfinding by avian motoneurons. Neuron 8:1031-1044.

Thanos S, Bonhoeffer F (1987) Axonal arborization in the developing chick retinotectal system. J Comp Neurol 261:155-164.

Thanos S, Dütting D (1988) Plasticity in the developing chick visual system: topography and maintenance of experimentally induced ipsilateral projections. J Comp Neurol 278:303-31 I.

Thanos S, Bonhoeffer F, Rutishauser U (1984) Fiber-fiber interaction and tectal cues influence the development of the chicken retinotectal projection. Proc Natl Acad Sci USA 81:1906-1910.

Venstrom KA, Reichardt LF (1993) Extracellular matrix 2: role of extracellular matrix molecules and their receptors in the nervous system. FASEB J 7:996-1003.

Volkmer H, Hassel B, Wolff JM. Frank R, Rathjen FG (1992) Structure of the axonal surface recognition molecule neurofascin and its relationship to a neural subgroup of the immunoglobulin superfamily. $J$ Cell Biol 118:149-161.

Watanabe M, Frelinger AL III, Rutishauser U (1986) Topography of N-CAM structural and functional determinants. I. Classification of monoclonal antibody epitopes. J Cell Biol 103:1721-1727.

Witte D, Gottlieb DI (1983) Time of appearance and tissue distribution of a cell surface antigen in early chick development. Brain Res 285: $63-67$.

Yamagata M, Sanes JR (1995) Lamina-specific cues guide outgrowth and arborization of retinal axons in the optic tectum. Development 121:189-200.

Yamagata M, Shinomura T, Kimata K (1993) Tissue variation of two large chondroitin sulfate proteoglycans (PG-M/versican and PG-H/ aggrecan) in chick embryos. Anat Embryol 187:433-444.

Yamagata M, Jaye DL, Sanes JR (1994) Gene transfer to avian embryos with a recombinant adenovirus. Dev Biol 166:355-359.

Zhang H, Miller RH, Rutishauser U (1992) Polysialic acid is required for optimal growth of axons on a neuronal substrate. J Neurosci 12: 3107-3114.

Zuellig RA, Rader C, Schroeder A, Kalousek MB, Von Bohlen und Halbach F, Osterwalder T, Inan C, Stoeckli ET, Affolter HU, Fritz A. et al. (1992) The axonally secreted cell adhesion molecule, axonin1. Primary structure, immunoglobulin-like and fibronectin-type-IIIlike domains and glycosyl-phosphatidylinositol anchorage. Fur J Biochem 204:453-463. 